\title{
Integrins as Therapeutic Targets for Respiratory Diseases
}

\author{
C.M. Teoh, S.S.L. Tan and T. Tran* \\ Department of Physiology, Yong Loo Lin School of Medicine, National University of
Singapore, Singapore
}

\begin{abstract}
Integrins are a large family of transmembrane heterodimeric proteins that constitute the main receptors for extracellular matrix components. Integrins were initially thought to be primarily involved in the maintenance of cell adhesion and tissue integrity. However, it is now appreciated that integrins play important roles in many other biological processes such as cell survival, proliferation, differentiation, migration, cell shape and polarity. Lung cells express numerous combinations and permutations of integrin heterodimers. The complexity and diversity of different integrin heterodimers being implicated

T. Tran in different lung diseases present a major challenge for drug development. Here we provide a comprehensive overview of the current knowledge of integrins from studies in cell culture to integrin knockout mouse models and provide an update of results from clinical trials for which integrins are therapeutic targets with a focus on respiratory diseases (asthma, emphysema, pneumonia, lung cancer, pulmonary fibrosis and sarcoidosis).
\end{abstract}

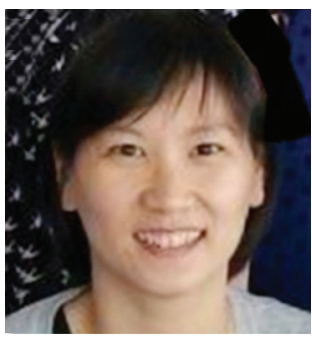

Keywords: Asthma, emphysema, integrins, lung cancer, lung disease, pulmonary fibrosis, sarcoidosis.

\section{INTRODUCTION}

Respiratory disease is defined as any disease that could impair lung functions. There are many types of respiratory diseases which include: 1) asthma and emphysema that obstruct the airflow of the lung, 2) pneumonia resulting from bacteria and virus infection, 3) lung cancer characterized by the uncontrolled growth and spread of abnormal cells, and 4) pulmonary fibrosis and sarcoidosis which stiffen and scar the lung. Despite the current standard treatments for various respiratory diseases, they remain the third leading killer with one in six deaths in the United States [1]. An estimated 400,000 Americans die from respiratory diseases every year and diseases such as asthma are associated with substantial health impairment and work disability [1].

Integrins are a large family of transmembrane proteins that constitute the main receptors for extracellular matrix (ECM) components. Integrins were initially thought to be primarily involved in the maintenance of cell adhesion and tissue integrity. However, further studies demonstrated that integrins also influence cell survival, proliferation, differentiation, migration, shape, polarity and other biological processes [2-5].

Upon interactions with ECM proteins, integrins activate downstream signaling pathways via direct or functional association with: 1) intracellular adaptors, such as p130Cas and Grb2; 2) cytosolic tyrosine kinases, such as Src family kinase (SFK) and focal

${ }^{*}$ Address correspondence to this author at the Department of Physiology, MD9, 2 Medical Drive, National University of Singapore, Singapore 117597, Singapore; Tel: +65 6516-3663;

E-mail: tran_thai@nuhs.edu.sg adhesion kinase (FAK); 3) growth factor receptors, such as epidermal growth factor receptor (EGFR) and platelet-derived growth factor (PDGF); and 4) cytokine receptors, such as IL-3 receptor to influence cell behaviors [6]. With these functions, integrins are implicated in many pathological processes of human respiratory diseases [7].

Here, we present an up-to-date review on the diverse biological activities of integrins with respect to their involvement in respiratory diseases, in particular asthma, emphysema, lung cancer, pneumonia, pulmonary fibrosis, and sarcoidosis.

\section{INTEGRIN GENE FAMILY}

The integrin family exists as non-covalently linked heterodimers of $\alpha$ - and $\beta$-subunits. There are $18 \alpha$ and $8 \beta$ subunits encoded by the human genome. To date, 24 functional integrin receptors have been described via various combinations of the $\alpha$ and $\beta$ subunits [8]. The ligand binding properties of integrins are defined by the $\alpha$ subunit, while the downstream signaling events are thought to be defined by the $\beta$ subunit [9]. Many $\alpha$ subunits associate with only a single $\beta$ subunit, while some $\alpha$ subunits associate with more than one $\beta$ subunit (for example, av may assemble with subunit $\beta 1, \beta 3, \beta 5, \beta 6$ and $\beta$ 8). Some integrins are able to recognize several ECM proteins, while others bind to only one type of ligand. Although in vitro studies have demonstrated considerable functional overlap among the integrin heterodimers, inactivation of individual integrins in mice has produced unique phenotypes (as discussed later). This suggests that the large number of integrins supports an array of unique functions.

Integrins are transmembrane receptors that mediate bi-directional signals through the cell membrane. On the cell surface, integrins exist in inactive, low affinity 
conformation states. With exception, Minagawa and colleagues showed that integrin $\alpha v \beta 8$ adopts a constitutively active, extended-closed headpiece conformation on the cell surface by hydrodynamic, mutational and electron microscopy methods and thus does not fit the conventional models of integrin activation [10]. It is believed that the function of integrin av $\beta 8$ is modulated by the metalloproteolytic cleavage of latent TGF- $\beta$ [11]. Integrins can signal through the cell membrane in both directions: inside-out signaling and outside-in signaling. The extracellular binding activity of integrins is regulated from the inside of the cell (inside-out signaling). Switching of affinity state of integrins to an active conformation allows for inside-out signaling. In contrast, the signals that are transmitted into the cells are elicited by the binding of ECM proteins on integrins (outside-in signaling) [12]. It is through these signaling activation events that integrins regulate cell attachment, survival, proliferation, cell spreading, differentiation, cytoskeleton organization, cell shape, cell migration, gene expression, tumorigenicity, intracellular $\mathrm{pH}$, and increase in concentration of cytosolic $\mathrm{Ca}^{2+}$ [13]. To activate downstream signaling pathways, integrins assemble signaling complexes termed "integrin adhesome" [14]. There are up to 156 distinct proteins in the integrin adhesome, some of which are fundamental to the adhesion site, while others only transiently associate. The integrin adhesome-associated proteins include talin, paxillin, filamin, integrin-linked kinase (ILK), FAK, p130Cas, SFK and GTPases of the Rho family [14-17].

One of the key signaling events upon integrin ligation is the activation of FAK. FAK is a non-receptor tyrosine kinase with $\mathrm{SH} 2$ domain binding sites. Upon integrin activation, integrins cluster and autophosphorylate at position tyrosine 397 (Y397). FAK binds to this phosphorylated site and recruits other proteins containing the $\mathrm{SH} 2$ domain. This includes the binding of SFK, leading to increased activation of the FAK-SFK complex which further phosphorylates downstream signaling players. One of the downstream targets of FAK is the Rho family of GTPases, which consists of Rac, Cdc42 and RhoA [18, 19]. Activation of Rac, Cdc42 and Rho A is critical for the organization of the actin cytoskeleton and for the recruitment of other signaling molecules to the focal adhesion site. FAK activation also recruits phosphatidylinositol-3-kinase (PI3K), leading to the activation of Akt $[5,20]$. The PI3K-Akt pathway mediates survival signaling via increased $\mathrm{Bcl}-2$ protein expression. In addition, FAK represents a crosstalk point with the growth factor receptor pathway [21]. Studies have shown that the activation of MEK1 and Raf1 via integrin mediated FAK-Src signaling is required for MAPK activation [22, 23]. This suggests that the integrin and growth factor receptor signaling may be integrated via the Ras-RafMEK-MAPK pathway to regulate key cellular functions such as cell proliferation.

\section{INTEGRIN EXPRESSION IN THE LUNG}

Integrins are expressed in various lung cell types and they may play important roles in regulating lung development. These include branching morphogenesis, epithelial cell polarization and differentiation. To determine the role of specific integrins in lung development, various studies have been done to investigate the expression patterns of integrins in foetal, human and murine lung developments [24-27].

Eight different integrins which include $\alpha 2 \beta 1, \alpha 3 \beta 1$, $\alpha 5 \beta 1, \alpha 6 \beta 4, \alpha 9 \beta 1, \alpha \vee \beta 5, \alpha v \beta 6$ and $\alpha \vee \beta 8$ are found to be expressed on human airway epithelial cells [28-33]. The expression patterns of these integrins in epithelial cells are different. For example, integrins $\alpha 3$ and $\alpha 6$ are diffusely expressed across the epithelial cells but integrin $\alpha 2$ is only found to be expressed on the branching tips of the cells [27]. Although epithelial cells express integrins $\alpha 3$ and $\alpha 6$, the subcellular distribution of these integrins are developmentally regulated. Young epithelial cells express integrins $\alpha 3$ and $\alpha 6$ pericellularly. As epithelial cells mature, they express integrins $\alpha 3$ and $\alpha 6$ basally [27, 34-36]. This suggests that integrins $\alpha 3$ and $\alpha 6$ might play an important role in lung epithelial maturation, development and basement membrane organization, whereas integrin $\alpha 2$ may be responsible for assembly and extension of epithelial tubule into mesenchyme in branching morphogeneisis. Integrins $\alpha 2 \beta 1$ and $\alpha 3 \beta 1$ are thought to play key roles in homotypic cell-cell interaction in the epithelium [3739]. However, the significance of this finding is uncertain since other studies have shown that there are no defects in epithelial cell-cell interactions in either integrin $\alpha 2-$ or $\alpha 3$-null mice [40-42]. The integrin a6ß4 is found to be important for the maintenance of epithelial integrity. This is evident by integrin $\alpha 6$ - or $\beta 4-$ null mice which die soon after birth due to severe skin blistering $[43,44]$. The other integrins $(\alpha 5 \beta 1, \alpha 9 \beta 1$ and $\alpha v \beta 5)$ are not expressed in healthy human epithelial cells but are rapidly induced on these cells upon lung inflammation and injury [11, 32, 45, 46]. Thus, these integrins serve as detectors to allow the lung cells to sense and respond to injury and inflammation in the lung.

Integrins such as $\alpha 1 \beta 1, \alpha 2 \beta 1, \alpha 5 \beta 1$ and $\alpha v \beta 3$ are expressed on lung endothelial cells. $W u$ and colleagues demonstrated that integrin $\alpha 1$ is stained positively on the airway endothelial cells and large blood vessels while integrin $\alpha 2$ is present on lung mesenchymal cells which mainly constitute the endothelium [27]. Another study showed that integrins $\alpha 5 \beta 1$ and $\alpha v \beta 3$ are expressed on the mesenchyme of the embryonic lungs [47]. This is supported by another study showing that integrin $\alpha v \beta 3$ is extensively evident in the endothelium of alveolar micro-vessels and vascular smooth muscle [48]. Taken together, these studies suggest that the integrins expressed on lung endothelial cells may regulate blood vessel formation and microvascular permeability. 
Other integrins such as $\alpha 2 \beta 1, \alpha 4 \beta 1, \alpha 5 \beta 1$, and $\alpha 11$ are expressed on lung fibroblasts, whilst integrins $\alpha 5 \beta 1, \alpha 7 \beta 1$ and $\alpha v \beta 5$ are expressed on airway smooth muscle. Integrins $\alpha 4 \beta 1, \alpha 5 \beta 1, \alpha E \beta 7$ and $\beta 2$ are expressed on respiratory $T$ lymphocytes and leukocytes [7, 49-56]. Collectively, all these studies demonstrate that there are differential expression of integrins during lung development and dysregulation of their expression in the lungs may contribute to respiratory diseases.

\section{INTEGRINS AND THEIR ASSOCIATION WITH RESPIRATORY DISEASES}

Table 1 summarizes the distribution of integrins in various lung cell types and their association with respiratory diseases. Fig. (1) illustrates integrin expressions in various respiratory diseases.

\section{INTEGRIN $\alpha 1 \beta 1$ IN ANGIOGENESIS}

The integrin $\alpha 1 \beta 1$ plays a key role in angiogenesis (formation of new blood vessels) and its expression is elevated in asthma, non-small-cell lung cancer (NSCLC) and sarcoidosis [57-59]. In asthma, angiogenesis constitutes one of the structural changes seen in airway wall remodeling. Activation of integrin $\alpha 1 \beta 1$ on endothelial cells is essential for VEGF-induced angiogenesis within the airway [57], thus promoting airway wall remodeling in asthmatic subjects. In NSCLC, the tumors are smaller and less vascularised in KrasLA2/a1-null mice when compared with KrasLA2/ $\alpha 1$ wild-type mice [58]. This suggests that the integrin $\alpha 1 \beta 1$ is involved in the growth of Kras-induced NSCLC, potentially by promoting angiogenesis.

\section{INTEGRIN $\alpha \mathbf{4} \beta 1$ IN INFLAMMATION}

The integrin $\alpha 4 \beta 1$ is expressed on cells in inflammatory diseases such as asthma, sarcoidosis and pulmonary fibrosis. Accumulation of leukocytes, mainly eosinophils in the airway is one of the characteristic features of asthma [60]. The integrin $\alpha 4 \beta 1$-expressing eosinophils are able to transmigrate across human pulmonary microvascular VCAM-1expressing endothelial cells [61]. Sarcoidosis is a chronic lung inflammation characterized by the accumulation of lymphocytes in the lung [7]. The overexpression of integrin $\alpha 4 \beta 1$ in human lymphocytes during sarcoidosis aids lymphocyte extravasation to the site of inflammation within the lung [49]. Collectively, these studies suggest that the integrin $\alpha 4 \beta 1$ plays an essential role in the recruitment of pro-inflammatory cells to the lung, contributing to inflammatory diseases.

\section{INTEGRIN $\alpha 5 \beta 1$ IN SURVIVAL AND ADHESION/ MIGRATION}

The integrin $\alpha 5 \beta 1$ is associated with asthma, epithelial injury and repair, NSCLC, pulmonary fibrosis and sarcoidosis due to its diverse roles in cell signaling. It primarily regulates the survival and adhesion/ migration signaling pathways. The expression of integrin $\alpha 5 \beta 1$ and its ECM ligand fibronectin are increased in the asthmatic airways [62]. Thus, the integrin mediated survival signaling from ECM proteins may be one of the mechanisms underlying the increased bulk of smooth muscle cells in airway wall remodeling [53]. In epithelial injury and repair, integrin $\alpha 5 \beta 1$ is required for epithelial cell migration and spreading for wound closure [32]. In NSCLC, increased expression of integrin $\alpha 5 \beta 1$ enhanced tumor cell survival and invasiveness on disrupted collagen matrix [63]. During pulmonary fibrosis, increased numbers of fibroblasts have been attributed to the migration/i nvasion of lung fibroblasts across the basement membrane to the site of wound via integrin $\alpha 5 \beta 1$ fibronectin signaling, leading to scarring of the lung [51]. In sarcoidosis, the integrin $\alpha 5 \beta 1$-fibronectin signaling is required for lymphocyte adhesion to the endothelial cells and their subsequent migration to the site of inflammation $[49,50]$. Taken together, these studies demonstrate that the integrin $\alpha 5 \beta 1$ is essential for the survival and adhesion/migration signaling of various cells in respiratory diseases.

\section{INTEGRIN $\alpha$ V $\beta 6$ IN TGF $\beta$ SIGNALING}

The integrin $\alpha v \beta 6$ mediates emphysema, NSCLC, pulmonary fibrosis, acute lung injury, influenza infection, epithelial injury and repair due to its ability to activate the TGF $\beta$ signaling pathway. Studies on integrin $\beta 6$ knockout mice suggest that integrin $\alpha v \beta 6$ may play a role in emphysema [64,65]. Loss of integrin av $\beta 6$ leads to the loss of latent TGF $\beta$ activation. Since TGF $\beta$ inhibits macrophage metalloelastase (MMP12), there is also a marked induction of MMP12 that degrades elastin. Therefore, integrin a6-null mice eventually develop age-dependent emphysema. In NSCLC, integrin $\alpha v \beta 6$ activates the release of active TGF $\beta$ from the ECM to promote tumor progression and invasion $[66,67]$. In patients with pulmonary fibrosis, integrin av $\beta 6$ is over-expressed in pneumocytes lining the alveolar ducts and alveoli [68]. Additionally, integrin av $\beta 6$ are dramatically upregulated in murine-model of bleomycin-induced pulmonary fibrosis [69]. The lungs of bleomycin-induced pulmonary fibrosis mice contained higher percentage and greater intensity of integrin av $\beta 6$-positive epithelial cells than the salinetreated mice [69]. The use of a blocking antibody further revealed that the partial inhibition of integrin av $\beta 6$ activation inhibits murine TGF $\beta$-mediated pulmonary fibrosis [68]. Jenkins and colleagues demonstrated that protease-activated receptor 1 activates TGF $\beta$ in an integrin $\alpha v \beta 6$-dependent manner via RhoA and Rho kinase signaling [70]. Another group while using lysophosphatidic acid to induce integrin av $\beta 6$-mediated activation of TGF $\beta$ showed that $G_{\alpha q}$ is an important link between integrin av $\beta 6$ to RhoA and Rho kinase signaling [71]. This pathway is a critical step in the development of acute lung injury and fibrosis [70, 71]. Jolly and colleagues also demonstrated that the influenza virus infection led to increased integrin $\alpha \vee \beta 6$-mediated TGF $\beta$ activation. The functional consequence of this is epithelial cell 
Table 1. Distribution of integrins in the lungs and their association with respiratory diseases.

\begin{tabular}{|c|c|c|c|c|c|}
\hline Disease & Integrin & ECM & Cell Type & Remarks & Ref. \\
\hline \multirow{10}{*}{ Asthma } & $\alpha 1 \beta 1$ & Collagen & \multirow{5}{*}{ Endothelial cell } & \multirow{5}{*}{$\begin{array}{l}\text { * Activation of } \alpha 1 \beta 1 \text { and } \alpha 2 \beta 1 \text { on endothelial cells } \\
\text { is essential for VEGF-induced angiogenesis in vivo. } \\
\text { * Successful early vasculogenesis and } \\
\text { angiogenesis require } \alpha 5 \beta 1 \text { integrin-fibronectin } \\
\text { interactions in vivo and in vitro. } \\
\text { * } \alpha v \beta 3 \text { and } \alpha v \beta 5 \text { are involved in angiogenesis of } \\
\text { the lung microvascular bed. }\end{array}$} & \multirow{5}{*}{$\begin{array}{l}{[57,108} \\
130-134]\end{array}$} \\
\hline & $\alpha 2 \beta 1$ & Collagen & & & \\
\hline & $\alpha 5 \beta 1$ & Fibronectin & & & \\
\hline & $\alpha v \beta 3$ & $\begin{array}{l}\text { Collagen; } \\
\text { Fibronectin; } \\
\text { Vitronectin }\end{array}$ & & & \\
\hline & $\alpha v \beta 5$ & $\begin{array}{l}\text { Collagen; } \\
\text { Fibronectin; } \\
\text { Vitronectin }\end{array}$ & & & \\
\hline & $\alpha 5 \beta 1$ & $\begin{array}{l}\text { Collagen; } \\
\text { Fibronectin; } \\
\text { Laminin }\end{array}$ & \multirow{3}{*}{$\begin{array}{l}\text { Airway smooth } \\
\text { muscle }\end{array}$} & $\begin{array}{l}\text { * Airway smooth muscle cells receive strong } \\
\text { survival signals from fibronectin, laminin and } \\
\text { collagen in vitro. }\end{array}$ & \multirow{3}{*}[47,56,62]{} \\
\hline & $\alpha 7 \beta 1$ & Laminin & & $\begin{array}{c}{ }^{*} \alpha 5 \beta 1 \text { and } \alpha 7 \beta 1 \text { are the transducer of survival } \\
\text { signals from ECM. }\end{array}$ & \\
\hline & $\alpha v \beta 5$ & $\begin{array}{l}\text { Collagen; } \\
\text { Fibronectin; } \\
\text { Vitronectin }\end{array}$ & & $\begin{array}{c}{ }^{*} \text { Airway smooth muscle cells express } \alpha v \beta 5 \\
\text { * av } \beta 5 \text { contributes to asthmatic airway remodeling } \\
\text { via TGF } \beta \text { activation }\end{array}$ & \\
\hline & $\alpha 4 \beta 1$ & $\begin{array}{l}\text { VCAM-1; } \\
\text { ICAM-4; } \\
\text { Osteopontin }\end{array}$ & $\begin{array}{l}\text { Eosinophil; } \\
\text { Lymphocyte; } \\
\text { Monocyte; } \\
\text { Macrophage; } \\
\text { Basophil; } \\
\text { Mast cell }\end{array}$ & 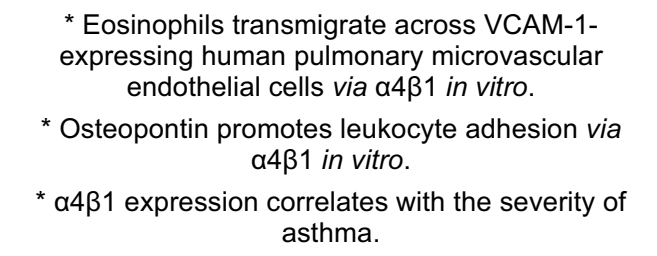 & $\begin{array}{l}{[61,116-} \\
118]\end{array}$ \\
\hline & $\alpha \mathrm{E} \beta 7$ & E-cadherin & T lymphocyte & $\begin{array}{l}\text { * Expression is enhanced on lymphocytes in } \\
\text { bronchoalveolar lavage fluid of asthma patients. }\end{array}$ & [55] \\
\hline \multirow[b]{2}{*}{ Emphysema } & $\begin{array}{l}\alpha 9 \beta 1 \\
\alpha v \beta 3 \\
\alpha v \beta 5\end{array}$ & Fibulin-5 & Elastic fiber & $\begin{array}{l}\text { * Fibulin-5 knockout mice exhibit disorganized } \\
\text { elastic fiber system throughout the body. } \\
\text { * Fibulin- } 5 \text { knockout mice have tortuous aorta, } \\
\text { severe emphysema and loose skin. } \\
\text { * Fibulin- } 5 \text { and its integrin partners stabilize and } \\
\text { organize elastic fiber in the skin, lung and } \\
\text { vasculature. }\end{array}$ & [135] \\
\hline & $\alpha v \beta 6$ & TGF $\beta$ & Epithelial cell & $\begin{array}{l}\text { * } \beta 6 \text { knockout mice have marked induction of } \\
\text { macrophage metalloelastase (MMP12) that } \\
\text { degrades elastin. } \\
\text { * } \beta 6 \text {-null mice develop age-dependent } \\
\text { emphysema. } \\
\text { * Loss of } \alpha \text { r } \beta 6 \text { mediated activation of latent TGF } \beta \\
\text { leads to age-dependent pulmonary emphysema via } \\
\text { alterations of Mmp12 expression. } \\
\text { * Functional alteration in the TGF } \beta \text { activation } \\
\text { pathway affects susceptibility to emphysema. }\end{array}$ & {$[64,65]$} \\
\hline $\begin{array}{l}\text { Epithelial } \\
\text { injury and } \\
\text { lung wound } \\
\text { repair }\end{array}$ & $\begin{array}{c}\alpha 2 \beta 1 \\
\alpha 3 \beta 1 \\
\alpha 5 \beta 1 \\
\alpha 6 \beta 1 \\
\alpha v ; \\
\beta 5 \\
\beta 6\end{array}$ & $\begin{array}{l}\text { Laminins; } \\
\text { Collagen; } \\
\text { Fibronectin; } \\
\text { Vitronectin; } \\
\text { Fibrinogen }\end{array}$ & Epithelial cell & $\begin{array}{c}\text { * Increased expression of } \alpha \mathrm{v}, \beta 5, \beta 6 \text { and } \alpha 5 \text { is } \\
\text { observed at the edges of surface epithelial wounds } \\
\text { in an in vivo xenograft model of human bronchial } \\
\text { epithelium. } \\
\text { * Similar up-regulation of } \alpha \mathrm{v}, \beta 5 \text { and } \beta 6 \text { is also } \\
\text { seen in areas of undifferentiated airway from cystic } \\
\text { fibrotic patients. } \\
\text { * Integrins mediate wound repair on different } \\
\text { constitutive ECM in a cultured human airway } \\
\text { epithelial cell line. } \\
\text { * } \beta 1 \text { is required for epithelial cell migration and } \\
\text { spreading for wound closure. }\end{array}$ & {$[32,136]$} \\
\hline
\end{tabular}


(Table 1) contd.....

\begin{tabular}{|c|c|c|c|c|c|}
\hline Disease & Integrin & ECM & Cell Type & Remarks & Ref. \\
\hline \multirow{5}{*}{ NSCLC } & $\alpha 1$ & Collagen & Epithelial cell & 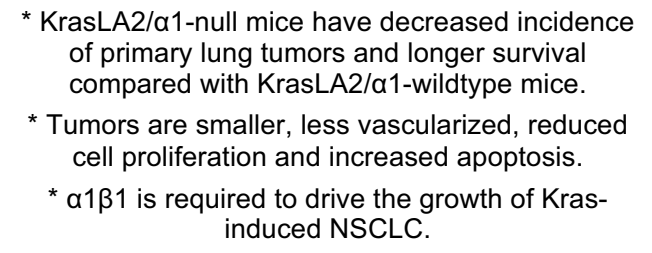 & [58] \\
\hline & $\alpha 5 \beta 1$ & Fibronectin & Epithelial cell & $\begin{array}{l}\text { * Lung cancer cell lines express high levels of a5. } \\
\text { * Node negative NSCLC samples have } \alpha 5 \text { over- } \\
\text { expression. } \\
{ }^{*} \text { a } 5 \text { expression is associated with the } \\
\text { differentiation status of the cancer cells and the } \\
\text { age of the patients. } \\
\text { * The overall survival rate for patients with node- } \\
\text { negative and over-expressed } \alpha 5 \text { NSCLS is lower } \\
\text { than patients with tumour of normal } \alpha 5 \text { expression. } \\
\text { * a5ß1 over-expression and the lost expression of } \\
\text { collagen matrices correlate with laminin metastasis } \\
\text { of NSCLC. } \\
\text { * Tumor cell survival and invasiveness are } \\
\text { promoted by the enhanced expression of } \alpha 5 \beta 1 \text { in } \\
\text { NSCLC. }\end{array}$ & {$[63,137]$} \\
\hline & $\alpha 11$ & $\begin{array}{l}\text { Collagen; } \\
\text { Fibroblast }\end{array}$ & $\begin{array}{l}\text { Stromal } \\
\text { fibroblast }\end{array}$ & $\begin{array}{c}\text { * Interaction between the collagen matrix and } \\
\text { stromal fibroblast via a11 regulates IGF2 } \\
\text { expression. } \\
\text { * IGF2 enhances NSCLC cell growth. }\end{array}$ & [52] \\
\hline & $\alpha v \beta 3$ & Osteopontin & Epithelial cell & $\begin{array}{l}{ }^{*} \text { Promotes lung cancer progression and } \\
\text { metastasis by boosting the } \alpha 5 \beta 1 \text {-EGFR signaling. }\end{array}$ & [138] \\
\hline & $\alpha v \beta 6$ & Fibronectin & Epithelial cell & $\begin{array}{l}\text { * Enhances the ability of tumor cells to adhere, } \\
\text { migrate, and invade the fibronectin-rich matrix that } \\
\text { surrounds NSCLC cells. } \\
\text { * Activates the release of active TGF } \beta \text { from ECM to } \\
\text { promote tumor progression and invasion. }\end{array}$ & {$[66,67]$} \\
\hline \multirow[b]{2}{*}{ Pneumonia } & $\alpha \mathrm{E} \beta 7$ & E-cadherin & T lymphocyte & $\begin{array}{l}{ }^{*} \text { Expression is enhanced on lymphocytes in } \\
\text { bronchoalveolar lavage fluid in patients. }\end{array}$ & {$[55]$} \\
\hline & $\beta 2$ & $\begin{array}{l}\text { VCAM; } \\
\text { ICAM }\end{array}$ & Leukocyte & $\begin{array}{l}\text { * Synergises with selectin on neutrophil adhesion } \\
\text { to endothelial cell. } \\
\text { * Aids in extravasation of leukocytes across the } \\
\text { vascular endothelium. }\end{array}$ & [7] \\
\hline \multirow{3}{*}{$\begin{array}{l}\text { Pulmonary } \\
\text { fibrosis }\end{array}$} & $\alpha 4 \beta 1$ & $\begin{array}{l}\text { VCAM; } \\
\text { ICAM }\end{array}$ & Fibroblast & $\begin{array}{l}{ }^{*} \text { Loss of } \alpha 4 \beta 1 \text { signaling via PTEN results in a } \\
\text { migratory/invasive phenotype of fibrotic lung } \\
\text { fibroblasts. }\end{array}$ & {$[51]$} \\
\hline & \multirow[b]{2}{*}{$\alpha 5 \beta 1$} & \multirow[b]{2}{*}{ Fibronectin } & Fibroblast & $\begin{array}{l}{ }^{*} \alpha 5 \beta 1 \text {-fibronectin signaling is required and } \\
\text { sufficient to induce lung fibroblast } \\
\text { migration/invasion across basement membrane }\end{array}$ & {$[51]$} \\
\hline & & & $\begin{array}{l}\text { Pneumocyte; } \\
\text { Endothelial cell; } \\
\text { Mesenchymal } \\
\text { cell; } \\
\text { Fibroblast; } \\
\text { Myofibroblast }\end{array}$ & $\begin{array}{c}{ }^{*} \alpha 5 \beta 1 \text { staining is apparent mainly on fibroblasts } \\
\text { and differentiated myofibroblasts after } 7 \text { days of } \\
\text { bleomycin treatment. } \\
{ }^{*} \alpha 5 \beta 1 \text { plays a key role in the activation, } \\
\text { proliferation, differentiation and increased ECM } \\
\text { synthesis of these cells during pulmonary } \\
\text { fibrogenesis. }\end{array}$ & [139] \\
\hline
\end{tabular}




\begin{tabular}{|c|c|c|c|c|c|}
\hline Disease & Integrin & ECM & Cell Type & Remarks & Ref. \\
\hline & $\alpha v \beta 6$ & $\begin{array}{l}\text { Collagen; } \\
\text { Fibronectin }\end{array}$ & Pneumocyte & $\begin{array}{c}\text { * av } \beta 6 \text { is over-expressed in penumocytes lining the } \\
\text { alveolar ducts and alveoli of human lung fibrosis. } \\
\text { * Partial inhibition of av } \beta 6 \text { activation via a blocking } \\
\text { antibody inhibits murine TGF } \beta \text {-mediated } \\
\text { pulmonary fibrosis without aggravating } \\
\text { inflammation. } \\
\text { * av } \beta 6 \text {, an activator of TGF } \beta \text {, is involved in the } \\
\text { pathophysiology of human pulmonary fibrosis. }\end{array}$ & {$[68,69,89]$} \\
\hline & $\alpha \mathrm{E} \beta 7$ & E-cadherin & T lymphocyte & $\begin{array}{l}\text { * Expression is enhanced on lymphocytes in } \\
\text { bronchoalveolar lavage fluid in patients. }\end{array}$ & [55] \\
\hline \multirow{5}{*}{$\begin{array}{l}\text { Sarcoidosi } \\
\text { s }\end{array}$} & $\alpha 4 \beta 1$ & $\begin{array}{l}\text { VCAM; } \\
\text { ICAM }\end{array}$ & $\begin{array}{c}\text { Alveolar T } \\
\text { lymphocyte; } \\
\text { Granuloma } \\
\text { lymphocyte }\end{array}$ & $\begin{array}{l}\text { * } \alpha 4 \beta 1 \text { is over-expressed in human lymphocytes } \\
\text { during the active phase of the disease. } \\
\text { * Interaction between VCAM- } 1 \text { and } \alpha 4 \beta 1 \text { is } \\
\text { important for the extravasation of lymphocytes to } \\
\text { the inflammatory site within the lung. }\end{array}$ & [49] \\
\hline & $\alpha 5 \beta 1$ & Fibronectin & $\begin{array}{l}\text { Alveolar T } \\
\text { lymphocyte; } \\
\text { Granuloma } \\
\text { lymphocyte; } \\
\text { Epitheloid cell; } \\
\text { Fibroblast }\end{array}$ & $\begin{array}{c}\text { * } \alpha 5 \beta 1 \text { is over-expressed in human lymphocytes, } \\
\text { epitheloid cells and fibroblasts during the active } \\
\text { phase of the disease. } \\
\text { * Interaction is important for cell proliferation, } \\
\text { cytokine production, and cell differentiation. } \\
\text { * } \alpha 5 \beta 1 \text {-fibronectin binding is important for adhesion } \\
\text { of leukocytes to the endothelial cells, to migrate } \\
\text { into inflammatory sites and to remain at the } \\
\text { affected sites via ECM binding. }\end{array}$ & {$[49,50]$} \\
\hline & $\alpha 1 \beta 1$ & Collagen & $\begin{array}{l}\text { Alveolar T } \\
\text { lymphocyte }\end{array}$ & $\begin{array}{l}\text { * } \alpha 1 \beta 1 \text { is over-expressed in human lymphocytes } \\
\text { during the active phase of the disease. } \\
\text { * The chronically stimulated lung T cells are } \\
\text { compartmentalized on the alveolar epithelial } \\
\text { surface and are gradually exchanged with the } \\
\text { systemic immune system via } \alpha 1 \beta 1 \text { integrin. }\end{array}$ & {$[49,140]$} \\
\hline & $\alpha 6 \beta 1$ & Laminin & $\begin{array}{l}\text { Granuloma } \\
\text { lymphocyte }\end{array}$ & $\begin{array}{c}{ }^{*} \alpha 6 \beta 1 \text { is over-expressed in human lymphocytes } \\
\text { during the active phase of the disease. }\end{array}$ & [49] \\
\hline & $\alpha 2 \beta 1$ & Collagens & Fibroblast & $\begin{array}{l}\text { * } \alpha 2 \beta 1 \text { is over-expressed in human lymphocytes } \\
\text { during the active phase of the disease. }\end{array}$ & {$[49,50]$} \\
\hline
\end{tabular}

apoptosis and increased collagen deposition, which are critical steps in exacerbations of pulmonary fibrosis [72, 73]. Collectively, these studies demonstrate that the integrin $\alpha v \beta 6$ is an activator of TGF $\beta$ and that functional alterations in the TGF $\beta$ signaling pathway increase the susceptibility to emphysema, NSCLC and pulmonary fibrosis.

\section{INTEGRIN $\alpha 7 \beta 1 \quad$ IN AIRWAY WALL REMODELING}

Airway wall remodeling is a prominent feature of asthma that contributes to chronic symptoms [74-76]. Airway wall remodeling is defined by a number of structural changes including increased mass of contractile airway smooth muscle cells, and fibrosis resulting from the accumulation of ECM proteins such as laminin. Increased expression of laminin is associated with asthma [77]. Our laboratory has recently demonstrated that the integrin $\alpha 7 \beta 1$ and its ECM protein laminin maintain and regulate contractile ASM phenotype and cell survival. This contributes to airway hyperresponsiveness and supports the enlargement of muscle bundles encircling the airways, a critical feature of airway wall remodeling [75]. Findings from our study suggests that targeting the laminin-integrin $\alpha 7 \beta 1$ signaling axis may offer new avenues for the development of therapies to reduce dysfunctions associated with contractile ASM cells in asthmatic patients.

\section{INTEGRIN $\alpha E \beta 7$ IN RESPIRATORY DISEASES}

The expression of the integrin $\alpha E \beta 7$ is enhanced on lymphocytes in the bronchoalveolar lavage fluid of patients with asthma, pneumonia and pulmonary fibrosis [55]. The integrin $\alpha E \beta 7$ is expressed only on lymphocytes of the intraepithelial phenotype [78, 79]. The only ligand for this integrin is the epithelial Ecadherin. The precise role of integrin $\alpha E \beta 7$ in these respiratory diseases is yet unknown but it has been suggested to be involved in the selective retention of lymphocytes in mucosal tissues of the lung during disease progression [55]. Further study in this area is warranted. 


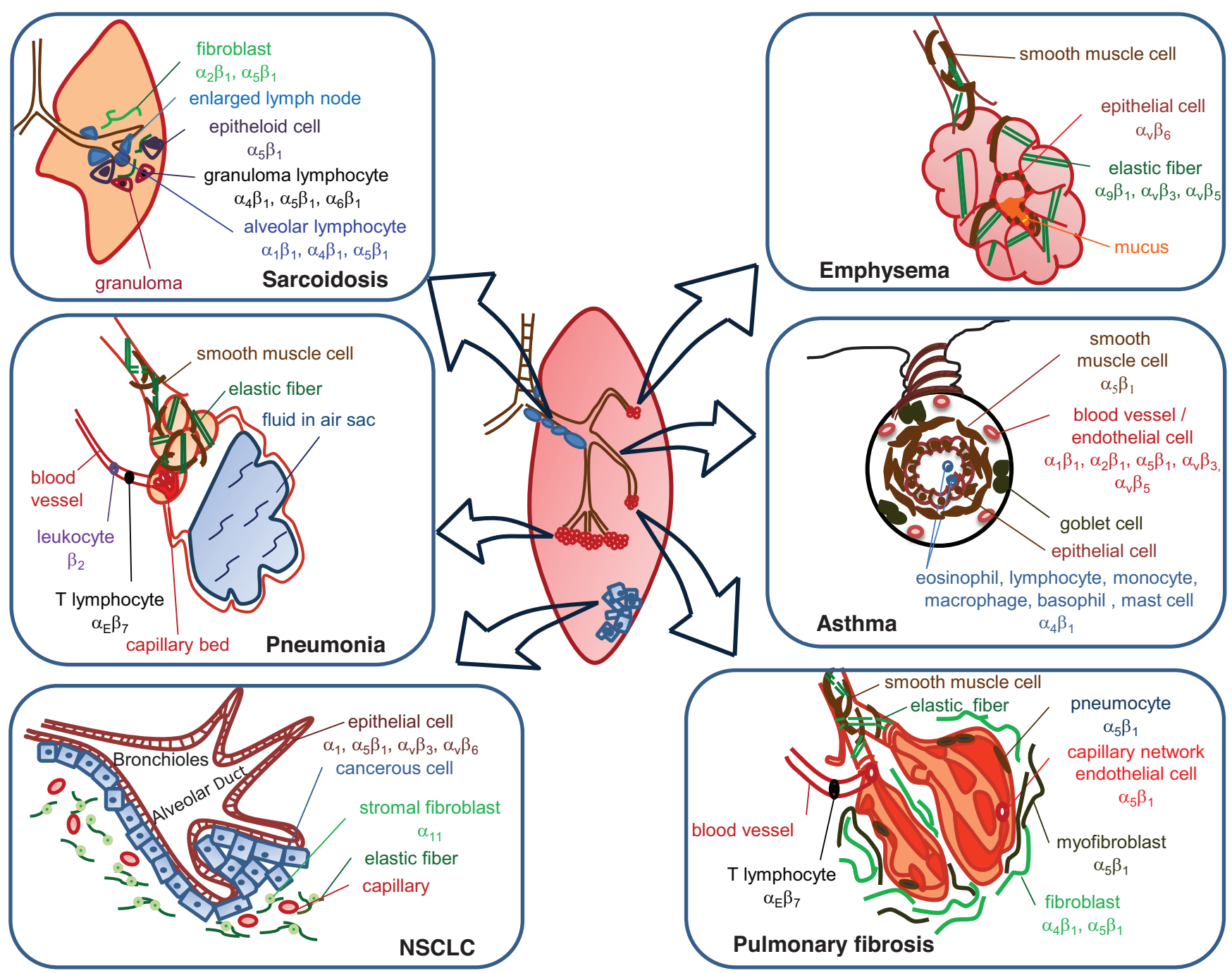

Fig. (1). Integrin expressions in various respiratory diseases.

\section{MATRICELLULAR PROTEINS AND THEIR ASSOCIATION WITH INTEGRINS IN RESPIRATORY DISEASES}

\section{Thrombospondin (TSP-1)}

TSP-1 is a major constituent of human blood platelets and it functions at the cell surface to bring together membrane proteins and cytokines that regulate the ECM and cellular phenotype [80]. TSP-1 interacts with integrins and is involved in respiratory diseases such as pneumonia, small cell lung carcinoma (SCLC) and pulmonary fibrosis.

Abnormalities were observed in the lungs of TSP-1 deficient mice. There is increased inflammatory cell infiltrates, fibroblastic and epithelial cell hyperplasia and matrix deposition in the lungs of these mice, and hemosiderein-laden macrophages were observed suggesting diffuse alveolar hemorrhage [81]. TSP-1 binds to integrins $\alpha 4 \beta 1$ and $\alpha 5 \beta 1$ in activated T-cell adhesion [82]. The binding of TSP-1 to integrins may aid in neutrophil adhesion and migration, monocytes chemotaxis, haptotaxis, and diapedesis [83-85]. The aberrant inflammation in TSP-1 deficient mice could be due to defects in recruitment and clearance of inflammatory cells via integrins. This results in pneumonia in the lungs of TSP-1 deficient mice, suggesting that TSP-1 is required in normal lung homoestasis [81].

In SCLC, the adhesion of cancer cells to TSP-1 was inhibited by heparin (integrin $\alpha 3 \beta 1$ inhibitor) [86]. The adhesion of SCLC cells to TSP-1 via integrin $\alpha 3 \beta 1$ induced neurite-like outgrowth and inhibited SCLC proliferation [86]. The TSP-1-integrin $\alpha 3 \beta 1$-induced neurotypic differentiation of SCLC is further enhanced by epidermal growth factor (EGF), suggesting that TSP-1 and EGF work synergistically to induce differentiation of SCLC via integrin $\alpha 3 \beta 1$ [86].

TSP-1 deficient mice are not protected from bleomycin-induced pulmonary fibrosis. These mice manifested higher expression of connective tissue growth factor and collagen deposition compared with wild type control mice [87]. This suggests that TSP-1 may basally suppress connective tissue growth factor and collagen expression. Moreover, TSP-1 deficiency 
appears to worsen pulmonary fibrosis in response to bleomycin. As TGF $\beta$ is involved in pulmonary fibrosis [88] and integrin $\alpha v \beta 6$ mediates TGF $\beta$ activation [89], TSP-1 may mediate the integrin $\alpha 6 \beta 1-T G F \beta$ activation in the pathogenesis of pulmonary fibrosis.

\section{SPARC}

Secreted Protein Acidic and Rich in Cysteine (SPARC) is a matricellular protein that mediates tissue repair and wound healing, and is a known target of TGF $\beta$ [90]. SPARC interacts with integrins and is involved in pulmonary fibrosis.

Immunohistochemical staining revealed that SPARC was observed in fibroblast of Masson bodies, fibroblast foci and interstitial fibroblast in pulmonary fibrosis [91]. SPARC binds to collagen III but not fibronectin [92]. Fibroblasts in the interstitial compartment of alveolar walls (collagen III rich) migrate to exudates in alveoli (fibronectin rich) during pulmonary fibrosis. Taken together, this suggests that SPARC may function early in pulmonary fibrosis by aiding fibroblast migration. SPARC regulates the production of integrin in an integrin-linked kinasedependent manner [93-95]. Barker and colleagues also demonstrated that SPARC modulates integrin-linked kinase activity in fibroblasts [96]. This suggests that migration of fibroblasts from alveolar walls to exudates in alveoli by SPARC may be integrin-dependent. Chang and colleagues showed that fibroblasts in pulmonary fibrosis have higher survival rate [97]. This may be attributed to elevated levels of SPARC which activates the PI3-Akt pathway via integrin, thus leading

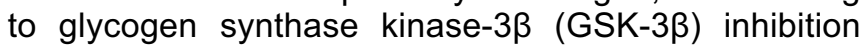
and $\beta$-catenin activation. $\beta$-catenin activation increased expression of plasminogen activator inhibitor-1 (PAl-1) which suppresses fibroblast apoptosis in pulmonary fibrosis. Therefore, the inhibition of SPARC-induced $\beta$ catenin signaling pathway may be a novel therapeutic target for pulmonary fibrosis [97].

\section{Periostin}

Periostin is an extracellular matrix protein induced by IL-4 and IL-13 in airway epithelial cells [98]. Its expression is also induced by TGF $\beta$ in fibroblasts [98]. Periostin interacts with integrins to mediate allergic lung inflammation, asthma, NSCLC and pulmonary fibrosis.

Allergen-challenged periostin-deficient mice developed reduced eosinophil infiltration in the lung compared with wild type mice [99]. This suggests a direct role of periostin in promoting allergen-induced eosinophil infiltration into the allergic inflammatory lungs. Recently, Takayama and colleagues demonstrated an upregulation of periostin in the lung epithelial cells by IL-13 and in the lungs of allergenchallenged wild-type mice [98]. Furthermore, periostin binds to integrins $\alpha \vee \beta 3$ and $\alpha v \beta 5$ to mediate fibroblast or malignant cell migration [100]. This suggests that the integrins expressed on eosinophils may bind to periostin on lung epithelial cells and thereby facilitate eosinophil recruitment to the lung of allergenchallenged mice.

In asthma, periostin deficiency leads to an increase in airway resistance and mucus production [101]. Allergen sensitization and challenge in periostin deficient mice had significantly higher PAS-staining index and Muc5ac and Gob5 expression compared with wild-type mice. This suggests that periostin attenuates mucus production that leads to airway resistance in asthma. Given that periostin binds to integrins $\alpha \vee \beta 3$ and $\alpha \vee \beta 5$ in cancer cells for adhesion and migration [100], it may also bind to integrins $\alpha 4$ and $\beta 1 / 2$ which are involved in asthma development and thus downregulate mucus production by repressing mucus production genes such as NF-KB. SP-1, and AP-1 [102]. The secretion of periostin is increased in lung fibroblasts in response to IL-4 and IL-13 stimulation, which are novel components of subepithelial fibrosis in bronchial asthma [98]. Secreted periostin binds ECM proteins such as fibronection, tenascin- $C$ and collagen $V$ [98]. Since the ECM proteins induce downstream signaling pathways via integrins, periostin-bound ECM proteins could potentially activate integrins, contributing to features of asthma.

In NSCLC, chemical hypoxia mimicking reagents increase periostin expression. The hypoxia responsive genes TGFa and bFGF induce the upregulation of periostin that in turn activates RTK/PI3K signaling cascade [103]. This signaling cascade confers survival of NSCLC. Bao and colleagues showed that periostin binds to integrin $\alpha v \beta 3$ to promote cancer cell metastasis by activating the $\mathrm{PI} 3 \mathrm{~K} / \mathrm{Akt}$ survival signaling pathway [104]. This suggests that periostin may interact with integrins to promote NSCLC survival via PI3K/Akt pathway.

In pulmonary fibrosis, periostin levels are elevated. Immunohistochemical staining showed that periostin stained mainly in areas of active fibrosis in the lung [105]. Okamoto and colleagues detected increased periostin levels in the lung of pulmonary fibrosis patients compared with healthy controls [106]. Periostin knockout mice were also protected from bleomycininduced pulmonary fibrosis [107]. Collectively, this suggests an important role of periostin in pulmonary fibrosis. Naik and colleagues demonstrated that TGF $\beta$ upregulates periostin expression in mesenchymal cells. Periostin in turn regulates ECM protein deposition, mesenchymal cell proliferation and wound closure, which are features of pulmonary fibrosis [105]. This suggests that TGF $\beta$-induced periostin play an important role in the late stages of pulmonary fibrosis. Importantly, when OC-20, an antibody that prevents periostin from binding to integrin, was administered 10 days post-bleomycin treatment in wild type mice, it significantly reduced bleomycin-associated fibrosis [105]. This suggests that periostin binds to integrin to mediate pulmonary fibrosis in the lung. 


\section{PHENOTYPES OF INTEGRIN KNOCKOUT MICE IN RELATION TO THE LUNG}

The availability of integrin knockout mice via gene targeting technology has increased our understanding of integrin functions. It reveals the unique functions each integrin have in the lung in vivo, whereby the deletion of a specific integrin results in distinctive phenotypes not shared by null mutations of other integrins. This is in contrast to the overlapping functions of integrins demonstrated in vitro. Table 2 summarizes the phenotypes of integrin knockout mice in relation to the lung.

Using integrin a1 knockout mice, Pozzi and colleagues showed that integrin $\alpha 1$ plays an important role in blood vessel formation in the lungs. Tumors implanted into these mice had reduced vascularization (reduced capillary number and size) [108]. This is due to the loss of integrin $\alpha 1$-induced tumor endothelial cell proliferation. In the same study, isolated a1-null endothelial cells from the lung also had reduced proliferation on the substrata. This suggests that the role of integrin $\alpha 1$ in angiogenesis is not restricted to tumor endothelial cells but also in the normal lung endothelial cells.

Kreidberg and colleagues demonstrated that the integrin a3 knockout mice showed severe decrease in bronchial branching and maturation of distal bronchioles [109]. In combination with other organ defects such as kidneys and cerebral cortex, integrin a3 knockout leads to death of mice shortly after birth [109-111]. Although both integrins $\alpha 3$ and $\alpha 6$ are expressed on lung epithelial cells, either integrin $\alpha 3$ or a6 knockout mice have normal lung development without any obvious lung defects [112]. Nonetheless, mice with double homozygous mutant for integrins a3 and a6 develop bilateral lung hypoplasia; a phenomenon characterized by low number and size of bronchopulmonary segments or alveoli in the lung [113]. This defect is not observed in either integrin a3 or a6 knockout mice, suggesting that the integrins $\alpha 3$ and a6 synergize in the normal development of the lung. It also suggests that the lack of either one integrin function may be compensated by the other to prevent bilateral lung hypoplasia.

Huang and colleagues showed that integrin a9 gene knockout mice exhibit increased volumes of pleural fluid, giving rise to bilateral chylothorax and respiratory failure [114]. The integrin a9-null mice also develop edema and lymphocytic infiltration (rich in lymphocytes, triglyceride, and cholesterol) in the chest wall. This study suggests that the integin $\alpha 9$ plays a critical role in the development of the thoracic duct and other lymphatic vessels essential for lung development.

Overall, studies in integrin knockout mice provided evidence that integrins promote respiratory disease progression and regulation of inflammation. The integrin $\beta 5$ knockout mice were protected from increased vascular permeability in a model of acute lung injury [115]. This may be attributed to decreased angiogenesis resulting from the loss of integrin $\beta 5$ on the pulmonary endothelial cells. The integrin $\alpha v \beta 6$ knockout mice showed age-dependent pulmonary emphysema due to the loss of TGF $\beta$ activation, leading to increased Mmp12 levels in the integrin av $\beta 6$-null mice and promoting emphysema development [65]. Integrin $\beta 6$ knockout mice also had severe lung inflammation (elevated lymphocyte accumulation in the conducting airways) and exhibited airway hyperresponsiveness to acetylcholine, a hallmark of asthma [64]. An enhanced lung inflammation observed in integrin $\beta 6$ knockout mice suggests the role of integrin av $\beta 6$ in downregulating inflammatory responses [89]. In this study, integrin $\beta 6$ knockout mice are protected from bleomycin-induced pulmonary fibrosis, a model that is critically dependent on TGF $\beta$ signaling. This protection against pulmonary fibrosis is not due to the downregulation of inflammatory response to bleomycin [89]. This suggests that integrin avß6 plays an important role in the development of pulmonary fibrosis.

\section{INTEGRINS IN CLINICAL TRIALS}

The diverse roles of integrins in the pathogenesis of respiratory diseases have placed them as potential targets for therapeutic interventions. Table 3 summarizes the integrin antagonists that are currently in the development for the treatment of respiratory diseases such as asthma and NSCLC.

Currently, only the integrin $\alpha 4 \beta 1$ is being targeted for the treatment of inflammation in asthma. This is because integrin $\alpha 4 \beta 1$ recruits leukocytes into the airway and exacerbates inflammation via VCAM and ICAM interactions [61, 116-118]. Integrin antagonists such as Valategrast (R411), IVL745, Bio 1211, GW559090X, HMR 1031 and TR14035 target these interactions [119, 120]. Nonetheless, they have failed to be effective during clinical trials. It is unclear whether the failure is due to the route of administration, bioavailability of the drugs, or attributed to functional compensation by the other integrins. Such integrins include integrin $\alpha 5 \beta 1$, which is found to be important for lymphocytes migration into the lung during sarcoidosis $[49,50]$.

Besides using integrin antagonists to treat inflammation in asthma, other aspects of asthma such as airway wall remodeling should also be considered. The formation of tortuous blood vessels and accumulation of smooth muscle bulks are common structural changes in asthmatic airways [121]. These processes are mainly regulated by integrins such as integrin $\alpha 1 \beta 1$ that increases angiogenesis and integrin $\alpha 5 \beta 1$ that mediates survival signals to airway smooth muscle cells [53]. Hence, drug therapies targeting the integrins $\alpha 1 \beta 1$ and $\alpha 5 \beta 1$ are warranted for the treatment of asthma. Airway wall remodeling is characterized by inflammation and fibrosis (increased deposition of ECM proteins) that deteriorates lung function. TGF $\beta$, a pleiotropic cytokine that drives the inflammation and matrix deposition is implicated in 
Table 2. Effect of integrin knockout in the lung development of mice.

\begin{tabular}{|c|c|c|c|}
\hline $\begin{array}{l}\text { Integrin } \\
\text { Knockout }\end{array}$ & Phenotype of Mice & Impact on Lung Development & Ref. \\
\hline$\alpha 1$ & $\begin{array}{l}\text { *Viable and fertile. } \\
\text { * No overt phenotype. } \\
\text { Vasculature } \\
\text { * Increased collagen synthesis. } \\
\text { * Increased Mmp7 and Mmp9 synthesis. } \\
\text { * Increased plasma levels of angiostatin. } \\
\text { * Implanted tumors show reduced vascularization. } \\
\text { Skin } \\
\text { * Embryonic fibroblasts fail to spread and migrate on collagen IV and } \\
\text { laminin in vitro. } \\
{ }^{*} \text { Hypocellular dermis. } \\
\text { * Reduced embryonic dermal fibroblast proliferation. }\end{array}$ & $\begin{array}{l}{ }^{*} \text { Isolated } \alpha 1 \text {-null endothelial } \\
\text { cells from the lung show } \\
\text { reduced proliferation on } \\
\text { substrata. } \\
{ }^{*} \text { Role of } \alpha 1 \text { integrin in } \\
\text { agiogenesis is not restricted to } \\
\text { tumor endothelial cells only. }\end{array}$ & {$[108,141-143]$} \\
\hline$\alpha 2$ & $\begin{array}{l}\text { *Viable, normal development and fertile. } \\
\text { * No obvious anatomical or histological differences. } \\
\text { Vasculature } \\
\text { * Display partially defective platelet adhesion to collagen. } \\
\text { * Platelets aggregate very slowly in the presence of collagen. } \\
\text { * No bleeding anomalies. } \\
\text { Mammary Gland } \\
\text { * Defects in branching morphogenesis of mammary gland. } \\
\text { Immunity } \\
\text { * Normal number of mast cells. } \\
\text { * Do not support mast cell-mediated inflammatory responses. } \\
\text { * Defects in innate immune response to Listeria monocytogenes. }\end{array}$ & * No abnormalities. & {$[144-147]$} \\
\hline$\alpha 3$ & $\begin{array}{l}\text { * Survive to birth but die during the neonatal period. } \\
\text { Kidney } \\
\text { * Defective branching of the medullary collecting duct despite normal } \\
\text { number of nephrons. } \\
\text { * Proximal tubule epithelial cells contain excess lysosomes and exhibit } \\
\text { microcystic. } \\
\text { * Disorganized glomerular basement membrane. } \\
\text { Skin } \\
\text { * Disorganized basement membrane of the skin. } \\
{ }^{*} \text { Skin blistering at the dermal-epidermal junction. } \\
\text { Brain } \\
\text { * Abnormal layering of the cerebral cortex. } \\
\text { * Developing cerebral cortex shows adhesive preference switch from } \\
\text { glial cells to neuronal tissues. }\end{array}$ & $\begin{array}{l}\text { * Decreased bronchus } \\
\text { branching. } \\
{ }^{*} \text { Large bronchi extend into the } \\
\text { periphery. } \\
{ }^{*} \text { Reduced maturation of distal } \\
\text { bronchiolar. } \\
\text { * } \alpha 3 \text { is important in regulating } \\
\text { basement membrane } \\
\text { organization and branching } \\
\text { morphogenesis. }\end{array}$ & {$[109-111,148]$} \\
\hline$\alpha 4$ & $\begin{array}{l}\text { * Embryonically lethal. } \\
\text { Placenta } \\
\text { * Defects in chorroallantois fusion during placental development. } \\
\text { Heart } \\
\text { * Abnormal development of the cardiac epicardium. } \\
\text { * Lack coronary vessels. } \\
\text { * Cardiac hemorrhage. } \\
\text { Face } \\
\text { * Abnormalities in the cranial and facial structure. } \\
\text { Lymphatic system } \\
\text { * Defects in lymphoid and myeloid lineage development. } \\
\text { * Defects in lymphocyte homing to Peyer's patches. }\end{array}$ & * Not determined. & {$[149-151]$} \\
\hline
\end{tabular}


(Table 2) contd.....

\section{Integrin}

Knockout

\begin{tabular}{|c|c|c|c|}
\hline$\alpha 5$ & $\begin{array}{l}{ }^{*} \text { Embryonically lethal. } \\
\text { Embroyonic Development } \\
\text { * Defects in extraembryonic and embryonic vasculature. } \\
\text { * Defects in posterior trunk and yolk sac mesodermal structures. } \\
\text { Vasculature } \\
{ }^{*} \text { Severe vascular defect. } \\
\text { Skeletal Muscle } \\
{ }^{*} \text { Develop typical alterations resembling muscular dystrophy. } \\
{ }^{*} \text { Reduced adhesion and survival of myoblasts. }\end{array}$ & $\begin{array}{l}\text { * Signs of thorax muscle } \\
\text { degeneration. } \\
\text { * a } 5 \text { maintains muscle integrity. }\end{array}$ & [152-155] \\
\hline$\alpha 6$ & $\begin{array}{l}{ }^{*} \text { Die shortly after birth. } \\
\text { Brain } \\
{ }^{*} \text { Abnormal laminar organization of the cerebral cortex. } \\
{ }^{*} \text { Ectopic neuroblastic outgrowth on the brain surface. } \\
{ }^{*} \text { Altered laminin deposition in the mutant brains. } \\
\text { Eye } \\
{ }^{*} \text { Abnormal laminar organization of the eye. } \\
{ }^{*} \text { Ectopic neuroblastic outgrowth on the eye. } \\
\text { Skin } \\
\text { * Severe skin blistering. }\end{array}$ & * No abnormalities. & [112] \\
\hline$\alpha 7$ & $\begin{array}{l}\text { *Viable and fertile. } \\
\text { Skeletal Muscle } \\
\text { * Develop symptoms of progressive muscular dystrophy soon after } \\
\text { birth. } \\
{ }^{*} \text { Severe disruption of the myotendinous junctions. } \\
\text { Heart } \\
\text { * } \text { Congenital myopathies. } \\
\text { Central Nervous System } \\
{ }^{*} \text { Delayed motor milestones. } \\
\text { * Impaired axonal regeneration. }\end{array}$ & * Not determined. & {$[156,157]$} \\
\hline$\alpha 8$ & $\begin{array}{l}\text { * Die soon after birth. } \\
\text { Kidney } \\
\text { * Profound deficits in kidney morphogenesis. } \\
{ }^{*} \text { Reduced branching and growth of the uretic bud. } \\
{ }^{*} \text { Mesenchymal cells fail to be recruited into the kidney epithelial } \\
\text { structures. } \\
\text { Ear } \\
{ }^{*} \text { Lacked / malformed stereocilia on hair cells in the utricle. } \\
\text { * Difficulty in balancing due to structural defects of the inner ear. }\end{array}$ & * Not determined. & {$[158,159]$} \\
\hline$\alpha 9$ & $\begin{array}{l}\text { * Born alive but develop bilateral chylothorax. } \\
\text { * Despite temporal and spatial expression of } \alpha 9 \text { on nonlymphatic } \\
\text { tissues (epithelium, airway and gut smooth muscle, choroid plexus and } \\
\text { liver) during development, its expression was not altered. } \\
\text { Bone } \\
\text { * Severe neutropenia due to the loss of } \alpha 9 \text { in bone marrow cells. } \\
\text { Lymphatic system } \\
\text { * Develop edema and lymphocytic infiltration in the chest wall. } \\
\text { * Abnormality in lymphatic development. }\end{array}$ & $\begin{array}{l}{ }^{*} \text { Respiratory failure caused by } \\
\text { an accumulation of large } \\
\text { volumes of pleural fluid. } \\
{ }^{*} \text { a9 plays a critical role in } \\
\text { development of the thoracic } \\
\text { duct and other lymphatic } \\
\text { vessels. }\end{array}$ & {$[114]$} \\
\hline
\end{tabular}




\begin{tabular}{|c|c|c|c|}
\hline $\begin{array}{l}\text { Integrin } \\
\text { Knockout }\end{array}$ & Phenotype of Mice & Impact on Lung Development & Ref. \\
\hline$\alpha 10$ & ${ }^{*}$ Not reported & & \\
\hline$\alpha v$ & $\begin{array}{l}{ }^{*} \text { Embryonically lethal. } \\
{ }^{*} \text { Conditional knockout of av on myofibroblasts in multiple organs } \\
\text { Organs } \\
{ }^{*} \text { Conditional knockout of av on myofibroblasts in liver, lung and kidney } \\
\text { inhibited fibrosis in these organs } \\
\text { Vasculature } \\
\text { * Defects in placenta, central nervous system, and gastrointestinal } \\
\text { blood vessels. } \\
{ }^{*} \text { Exhibit intracerebral and intestinal hemorrhages. } \\
{ }^{*} \text { Extensive vasculogenesis and angiogenesis in knockout mice despite } \\
\text { the role of av integrin in vascular development. } \\
\text { Mouth } \\
{ }^{*} \text { Cleft palates. }\end{array}$ & * Not determined. & {$[160,161]$} \\
\hline$\alpha \mathrm{L}$ & $\begin{array}{l}\text { Immunity } \\
\text { * Impaired lymphocyte recirculation and homotypic interactions. } \\
\text { * Reduced leukocyte proliferation in response to mixed lymphocyte } \\
\text { reaction and growth factor in vitro despite normal cytotoxic T cell } \\
\text { responses. } \\
\text { * No rejection of immunogenic tumors grafted into footpads. } \\
\text { * No priming responses towards tumor-specific antigen. } \\
\text { * Impaired induction of peripheral immune responses but respond to } \\
\text { systemic infection. }\end{array}$ & ${ }^{*}$ Not determined. & [162-164] \\
\hline$\alpha \mathrm{M}$ & $\begin{array}{l}{ }^{*} \text { Obesity. } \\
\text { Immunity } \\
{ }^{*} \text { Impaired phagocytosis, polymorphonuclear leucocytes (PMN) } \\
\text { apoptosis, and mast cell development. }\end{array}$ & * Not determined. & [165-167] \\
\hline$\alpha \mathrm{E}$ & $\begin{array}{l}\text { Immunity } \\
\text { * Reduced number of intestinal and vaginal intraepithelial lymphocytes. } \\
\text { * Diminished lamina propia T lymphocytes numbers. } \\
\text { * Number of T lymphocytes is not altered in Peyer's patch and spleen. }\end{array}$ & $\begin{array}{l}{ }^{*} \text { Peribronchial and } \\
\text { intrapulmonary T lymphocytes } \\
\text { numbers are not reduced. } \\
{ }^{*} \alpha E \text { plays a role in generating } \\
\text { and maintaining the gut and } \\
\text { vaginal T lymphocytes (but not } \\
\text { in the lungs). }\end{array}$ & [168] \\
\hline allb & $\begin{array}{l}\text { Vasculature } \\
\text { * Defective platelet function caused by the failure of platelets to bind } \\
\text { fibrinogen, to aggregate and to retract fibrin clot. } \\
\text { * Lack of fibrinogen in platelet granules. } \\
\text { * Increased rebleeding tendency similar to Glanzmann thrombasthenia } \\
\text { in humans. }\end{array}$ & * Not determined. & [169] \\
\hline$\alpha X$ & ${ }^{*}$ Not reported. & & \\
\hline$\alpha D$ & * Not reported. & & \\
\hline$\beta 1$ & $\begin{array}{l}\text { * Peri-implantation lethality. } \\
\text { Embroyonic Development } \\
\text { * Inner cell mass deterioration due to the lost of } \beta 1 \text { integrin-mediated } \\
\text { survival signaling. } \\
\text { Heart } \\
{ }^{*} \text { Cardiac muscle in the heart becomes smaller and degenerates. } \\
\text { * Alterations in the sarcomeric architecture. } \\
{ }^{*} \text { Hypertrophic changes in the heart. } \\
\text { * Display replacement fibrosis - the formation of fibrous tissues at sites } \\
\text { where the cells are atrophied, degenerated and necrotic. } \\
\text { Bone } \\
\text { * Impaired membranous bone formation, characterized by decreased } \\
\text { cortical bone formation and reduced bone mass in cortical and flat } \\
\text { bones. }\end{array}$ & ${ }^{*}$ Not determined. & {$[170-174]$} \\
\hline
\end{tabular}


(Table 2) contd....

\section{Integrin}

\begin{tabular}{|c|c|c|c|}
\hline$\beta 2$ & $\begin{array}{l}\text { Immunity } \\
\text { * Impaired leukocyte recruitment. } \\
\text { * Develop chronic dermatitis with extensive erosion on face and } \\
\text { submandibular region. } \\
\text { * Increased neutrophil counts, elevated immunoglobulin levels, } \\
\text { splenomegaly, lymphadenopathy and abundant plasma cells in skin, } \\
\text { gut, kidney and lymph nodes. } \\
\text { * Severe defect in T cell proliferation. } \\
\text { * Reduced neutrophil extravasation into infected tissues during irritant } \\
\text { dermatitis. }\end{array}$ & $\begin{array}{l}\text { * In pneumonia, the neutrophil } \\
\text { emigration in lung section is not } \\
\text { reduced compared to wild type } \\
\text { mice. } \\
{ }^{*} \beta 2 \text { is essential only for dermal } \\
\text { neutrophil emigration during } \\
\text { skin infection. } \\
{ }^{*} \text { Reduced number of dendritic } \\
\text { cells in the lung, alveolar wall, } \\
\text { large and small airways. } \\
\text { * } \beta 2 \text { is required for dendritic cell } \\
\text { migration into the lung. }\end{array}$ & [175-177] \\
\hline$\beta 3$ & $\begin{array}{l}\text { *Viable and fertile. } \\
\text { Vasculature } \\
\text { * Display cardinal features of Glanzmann thrombasthenia - defective } \\
\text { platelet aggregation, impaired clot retraction and increased rebleeding } \\
\text { tendency. } \\
{ }^{*} \text { Reduced survival and anemia due to postnatal hemorrhage. } \\
\text { Placenta } \\
\text { * Placental defects leading to fetal mortality despite normal } \\
\text { implantation. } \\
\text { Bone } \\
{ }^{*} \text { Develop osteosclerosis - increased bone mass with age. } \\
\text { * Contain more osteoclasts despite increased bone mass. However, } \\
\text { osteoclasts are dysfunctional as evidenced by significant hypocalcemia } \\
\text { in knockout mice. }\end{array}$ & * Not determined. & [178-180] \\
\hline$\beta 4$ & $\begin{array}{l}{ }^{*} \text { Die shortly after birth. } \\
{ }^{*} \alpha 6 \text { subunit significantly downregulated. } \\
\text { Skin } \\
{ }^{*} \text { Display pathological phenotype similar to human junctional } \\
\text { epidermolysis bullosa. } \\
\text { * Skin blistering with severe epidermis and squamous epithelial } \\
\text { detachment. } \\
\text { * Reduced skin adhesive properties due to the absence of } \\
\text { hemidesmosomes. } \\
{ }^{*} \text { Epithelial tissues show signs of degeneration and disorganization. }\end{array}$ & ${ }^{*}$ Not determined. & {$[44,181]$} \\
\hline$\beta 5$ & $\begin{array}{l}{ }^{*} \text { Develop, grow and reproduce normally. } \\
\text { Skin } \\
{ }^{*} \text { Harvested keratinocytes demonstrate defects in migration and } \\
\text { adhesion on vitronectin in vitro. However, cutaneous wound healing is } \\
\text { the same as wild type mice. } \\
\text { Eye } \\
{ }^{*} \text { Age-related blindness. }\end{array}$ & $\begin{array}{l}\text { * Protection from increased } \\
\text { vascular permeability in a model } \\
\text { of acute lung injury. } \\
\text { * } \beta 5 \text { from pulmonary endothelial } \\
\text { cells regulates vascular } \\
\text { permeability in acute lung injury. } \\
\text { * } \beta 5 \text { deletion did not affect } \\
\text { adenovirus infection. }\end{array}$ & [182] \\
\hline$\beta 6$ & $\begin{array}{l}\text { Skin } \\
\text { * Skin inflammation. } \\
\text { * Juvenile baldness due to macrophage infiltration to the dermis of the } \\
\text { affected area. }\end{array}$ & $\begin{array}{l}{ }^{*} \text { Accumulation of activated } \\
\text { lymphocytes around conducting } \\
\text { airways during lung } \\
\text { inflammation. Hence, there is } \\
\text { airway hyperresponsiveness to } \\
\text { increasing acetylcholine } \\
\text { stimulation. } \\
{ }^{*} \beta 6 \text { regulates local } \\
\text { inflammation of lung epithelial } \\
\text { cells. } \\
{ }^{*} \beta 6 \text { activates TGF } \beta \text {, a signaling } \\
\text { pathway essential for pulmonary } \\
\text { fibrosis. Hence, these mice are } \\
\text { protected from lung fibrosis. }\end{array}$ & {$[64,89]$} \\
\hline$\beta 7$ & $\begin{array}{l}\text { Gut associated Lymphoid Tissue (GALT) } \\
\text { * Abnormal Peyer's patches. } \\
\text { * Defective migration of T cells to Payer's patches. } \\
\text { * Decreased number of lamina propia intraepithelial lymphocytes. }\end{array}$ & $\begin{array}{l}{ }^{*} \beta 7 \text { is required for lymphocytes } \\
\text { to adhere on vasculature at the } \\
\text { site for transmigration into the } \\
\text { GALT. }\end{array}$ & [183] \\
\hline
\end{tabular}




\begin{tabular}{|c|c|c|c|}
\hline $\begin{array}{l}\text { Integrin } \\
\text { Knockout }\end{array}$ & Phenotype of Mice & Impact on Lung Development & Ref. \\
\hline$\beta 8$ & $\begin{array}{l}\text { Vasculature } \\
\text { * Defects in placenta, central nervous system and gastrointestinal } \\
\text { blood vessels. } \\
\text { Mouth } \\
{ }^{*} \text { Cleft palate. }\end{array}$ & * Not determined. & {$[184]$} \\
\hline$\alpha v \beta 6$ & ${ }^{*}$ Marked increase in macrophage metalloelastase level (MMP12) & $\begin{array}{l}{ }^{*} \text { Loss of } \alpha \text { v } \beta 6 \text {-mediated } \\
\text { activation of latent TGF } \beta \text { causes } \\
\text { age-dependent pulmonary } \\
\text { emphysema through alterations } \\
\text { in macrophage MMP12 } \\
\text { expression. }\end{array}$ & {$[65,89,185]$} \\
\hline$\alpha 6 \beta 4$ & $\begin{array}{l}\text { Skin } \\
{ }^{*} \text { Complete absence of hemidesmosomes. } \\
{ }^{*} \text { Skin blistering leading to postnatal death. } \\
{ }^{*} \text { Epidermolysis bullosa with congenital pyloric atresia. }\end{array}$ & ${ }^{*}$ Not determined. & [186] \\
\hline$\alpha 5$ and $\alpha v$ & $\begin{array}{l}\text { * Embryonically lethal. } \\
\text { Embroyonic Development } \\
\text { * Display severe gastrulation defect with a lack of anterior mesoderm. } \\
\text { * Severe amniotic defect similar to fibronectin-null mice. }\end{array}$ & ${ }^{*}$ Not determined. & [153] \\
\hline$\alpha 3$ and $\alpha 6$ & $\begin{array}{l}\text { * Growth retarded. } \\
\text { Limb } \\
\text { * Limb abnormalities - syndactyly and fusion of preskeletal elements. } \\
\text { * Defects in the apical ectodermal ridge, a limb organizing centre. } \\
\text { Brain } \\
\text { * Exencephaly - absence of neural tube closure. } \\
\text { * Cortical disorganization } \\
\text { Kidney } \\
\text { * Kidney defects } \\
\text { * Structural disorganization and reduced proliferation of the ridge cells. } \\
\text { Eye } \\
\text { * Eye lamination defects }\end{array}$ & $\begin{array}{l}\text { * Develop bilateral lung } \\
\text { hypoplasia } \\
{ }^{*} \alpha 3 \text { and } \alpha 6 \text { integrins are } \\
\text { required for structural } \\
\text { organization of presumptive } \\
\text { ectodermal ridge cells for } \\
\text { normal lung development. }\end{array}$ & $\begin{array}{c}{[113,155} \\
187]\end{array}$ \\
\hline $\begin{array}{l}\beta 7 \text { and L- } \\
\text { selectin }\end{array}$ & $\begin{array}{l}\text { Immunity } \\
\text { * Suffer from a nearly complete impairment of lymphocyte migration to } \\
\text { mesenteric lymph nodes (MLN). } \\
\text { * Impaired MLN formation. } \\
\text { * T lymphocyte numbers drastically reduced compared to control mice. }\end{array}$ & * Not determined. & [188] \\
\hline
\end{tabular}

asthmatic and COPD airway remodeling [122-124]. The activation of TGF $\beta$ is integrin $\alpha \vee \beta 55-$ and $\alpha v \beta 8$ dependent and these two integrins have been shown to be expressed on airway smooth muscle cells ( $\alpha \vee \beta 5$ ) and airway fibroblasts ( $\alpha \mathrm{v} \beta 8$ ) and their expression are increased in asthma and COPD [10, 56, 125]. Hence, integrins $\alpha \vee \beta 5$ and $\alpha \vee \beta 8$ represent attractive targets for the treatment of airway remodeling in asthma and COPD.

Besides utilizing integrin antagonists, integrin inhibitors have been conjugated to cytotoxic drugs. This is done by synthetic chemistry or by coupling the inhibitors to biomacromolecules via DNA recombination technology or fusion protein technology to facilitate drug delivery into the targeted cells, such as cancerous cells in NSCLC and leukocytes in asthma [126]. For example, the ACDCRGDCFC peptide is conjugated with the antimicrobial synthetic peptide (KLAKLAK) ${ }_{2}$ and targets the integrins $\alpha \vee \beta 3$ and $\alpha \vee \beta 6$ in NSCLC [127]. ACDCRGDCFC is a targeting domain for integrins $\alpha \vee \beta 3$ and $\alpha \vee \beta 6$, which homes the proapoptotic peptide to the targeted cells for further internalization. $(\mathrm{KLAKLAK})_{2}$ is a proapoptotic domain. This conjugation is designed to be toxic only when internalized into the cells because it specifically disrupts mitochondrial membranes. It shows significant tumour reducing effect and reduced lung metastasis burden in preclinical trials [127].

Some integrin antagonists are applied in combination with the standard anti-cancer therapies. One such example is Vitaxin II which targets the integrin $\alpha v \beta 3$ in NSCLC. It is currently under Phase I clinical trial [19]. Other integrin antagonists that are currently under Phase II clinical trials for NSCLC are Cilengitide and Volociximab. Cilengitide targets the integrins $\alpha \vee \beta 3$ and $\alpha \vee \beta 5$ whereas Volociximab targets 
Table 3. Targeted integrins in clinical trials.

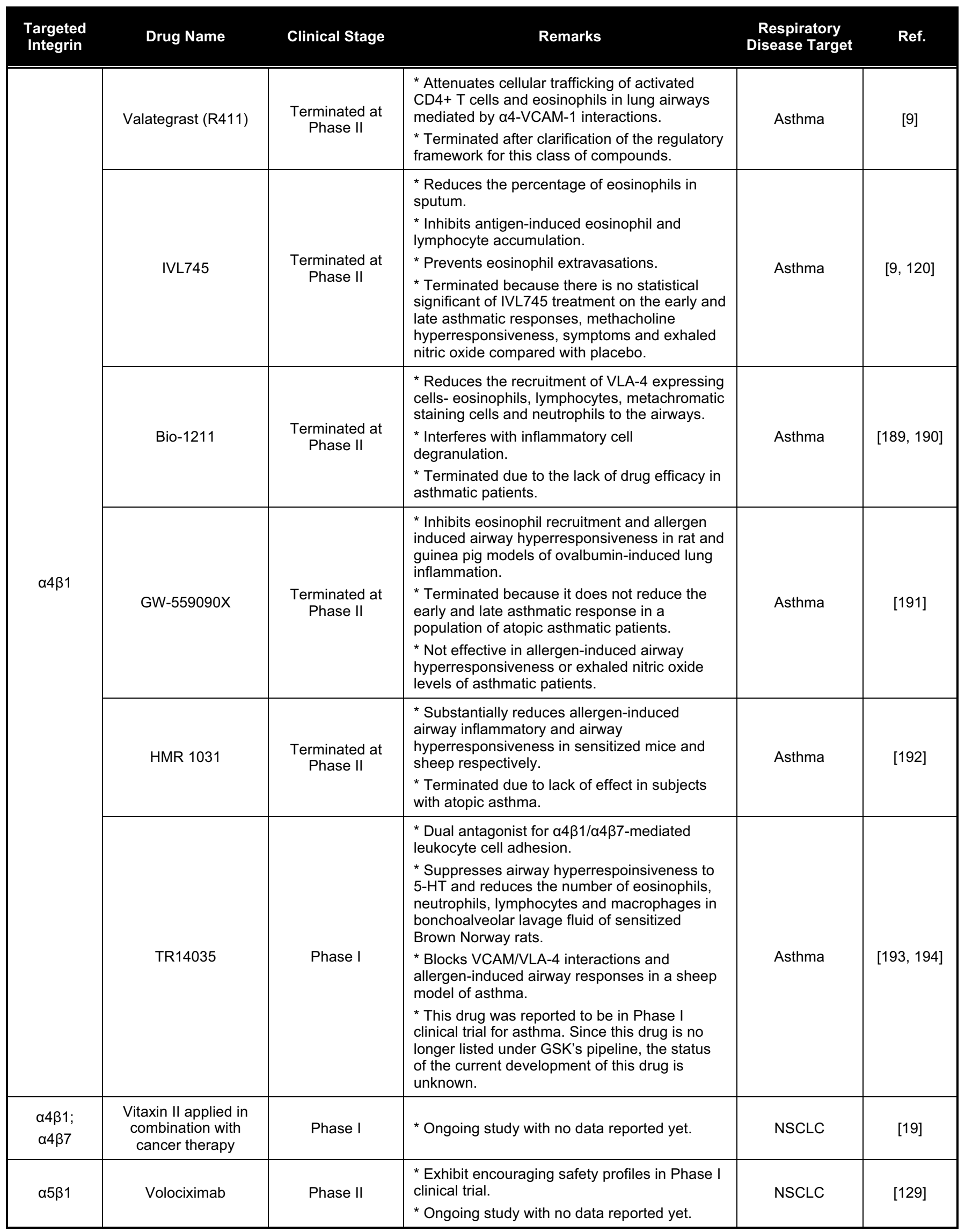




\begin{tabular}{|c|c|c|c|c|c|}
\hline $\begin{array}{l}\text { Targeted } \\
\text { Integrin }\end{array}$ & Drug Name & Clinical Stage & Remarks & $\begin{array}{c}\text { Respiratory } \\
\text { Disease Target }\end{array}$ & Ref. \\
\hline$\alpha v \beta 3$ & $\begin{array}{l}\text { ACDCRGDCFC } \\
\text { peptide } \\
\text { conjugated } \\
\text { with } \\
\text { antimicrobial } \\
\text { synthetic } \\
\text { peptide } \\
(\mathrm{KLAKLAK})_{2}\end{array}$ & Preclinical & $\begin{array}{l}\text { * ACDCRGDCFC - a targeting domain to guide } \\
\text { the "homing' proapoptotic peptide to the } \\
\text { targeted cells and allow internalization. } \\
\text { * (KLAKLAK })_{2} \text { - a proapoptotic domain } \\
\text { designed to be non-toxic outside the cells but } \\
\text { toxic when internalized into targeted cells by } \\
\text { the disruption of mitochondrial membranes. } \\
\text { * Significant tumor-reducing effect. } \\
\text { * Able to lower the lung metastasis burden. }\end{array}$ & NSCLC & {$[127]$} \\
\hline $\begin{array}{l}\alpha v \beta 3 \\
\alpha v \beta 5\end{array}$ & Cilengitide & Phase II & $\begin{array}{l}\text { * Exhibit encouraging safety profiles in Phase I } \\
\text { clinical trial. } \\
\text { * Ongoing study with no data reported yet. }\end{array}$ & NSCLC & {$[128,195]$} \\
\hline
\end{tabular}

the integrin $\alpha 5 \beta 1$. Both drugs have anti-angiogenic effect in NSCLC and showed encouraging safety profiles in Phase I trials [128, 129].

Currently, there are only 3 integrins $\alpha$ av $\beta 3, \alpha v \beta 5$ and $\alpha 5 \beta 1)$ targeted in NSCLC. These integrins are targeted mainly for their anti-angiogenic function in tumors. Given that other integrins ( $\alpha 1, \alpha 11$ and $\alpha v \beta 6)$ are also involved in NSCLC disease progression, antagonists against these integrins should be considered for therapeutic development $[52,58,66,67]$.

The study of integrin antagonists should also be extended to other lung diseases such as emphysema, epithelial injury and repair, pulmonary fibrosis, pneumonia and sarcoidosis, whereby integrins play important roles (Table 1).

\section{CONCLUSION}

We have reviewed and highlighted the importance of integrins in mediating various respiratory disease progressions. Integrins are promising therapeutic targets. Nonetheless, the complexity and diversity of integrins present a major challenge for drug development. Recent advances in the understanding of the integrin function and their signaling mechanisms using the gene knockout technology have aided in the development of integrin antagonists. This is coupled with the possibility of altering integrin signaling in respiratory diseases. Collectively, drugs targeting integrins hold great potential for the treatment of respiratory diseases in the future.

\section{ABBREVIATIONS}

$$
\begin{array}{ll}
\text { ECM } & =\text { Extracellular matrix } \\
\text { EGFR } & =\text { Epidermal growth factor receptor } \\
\text { FAK } & =\text { Focal adhesion kinase } \\
\text { GALT } & =\text { Gut associated lymphoid tissues } \\
\text { ILK } & =\text { Integrin-linked kinase } \\
\text { MLN } & =\text { Mesenteric lymph nodes } \\
\text { MMP12 } & =\text { Macrophage metalloelastase } \\
\text { NSCLC } & =\text { Non-small cell lung cancer }
\end{array}
$$

$$
\begin{aligned}
& \text { NSCLC }=\text { non-small cell lung cancer } \\
& \text { PDGF }=\text { Platelet-derived growth factor } \\
& \text { PI3K }=\text { Phosphatidylinositol-3-kinase } \\
& \text { PMN }=\text { Polymorphonuclear leucocytes } \\
& \text { SFK }=\text { Src family kinase }
\end{aligned}
$$

\section{CONFLICT OF INTEREST}

The authors confirm that this article content has no conflict of interest.

\section{ACKNOWLEDGEMENTS}

TT received funding support from the Singapore Ministry of Health's National Medical Research Council under its IRG scheme (NMRC/1215/2009).

\section{REFERENCES}

[1] Miniño AM, Heron MP, Murphy SL, et al. Deaths: final data for 2004. Natl Vital Stat Rep 2007; 55(19): 1-119.

[2] Hynes RO. Integrins: versatility, modulation, and signaling in cell adhesion. Cell 1992;69(1):11-25.

[3] Hood JD, Cheresh DA. Role of integrins in cell invasion and migration. Nat Rev Cancer 2002; 2(2): 91-100.

[4] Humphries MJ. Integrin structure. Biochem Soc Trans 2000; 28(4): 311-39.

[5] Giancotti FG, Ruoslahti E. Integrin signaling. Science 1999; 285(5430): 1028-32.

[6] Cabodi S, Di Stefano P, Leal MeP, et al. Integrins and signal transduction. Adv Exp Med Biol 2010; 674: 43-54.

[7] Bazan-Socha S, Bukiej A, Marcinkiewicz C, et al. Integrins in pulmonary inflammatory diseases. Curr Pharm Des 2005;11(7): 893-901.

[8] van der Flier A, Sonnenberg A. Function and interactions of integrins. Cell Tissue Res 2001; 305(3): 285-98.

[9] Cox D, Brennan M, Moran N. Integrins as therapeutic targets: lessons and opportunities. Nat Rev Drug Discov 2010; 9(10): 804-20.

[10] Minagawa S, Lou J, Seed RI, et al. Selective targeting of TGF- $\beta$ activation to treat fibroinflammatory airway disease. Sci Transl Med 2014; 6(241): 241ra79.

[11] Mu D, Cambier S, Fjellbirkeland L, et al. The integrin alpha(v)beta8 mediates epithelial homeostasis through MT1MMP-dependent activation of TGF-beta1. J Cell Biol 2002; 157(3): 493-507.

[12] Giancotti F, Ruoslahti E. Integrin signaling. Science 1999; 285(5430): 1028-32. 
[13] Ross R. Molecular and mechanical synergy: cross-talk between integrins and growth factor receptors. Cardiovasc Res 2004; 63(3): 81-90.

[14] Zaidel-Bar R, Itzkovitz S, Ma'ayan A, et al. Functional atlas of the integrin adhesome. Nat Cell Biol 2007; 9(8): 858-67.

[15] Harburger DS, Calderwood DA. Integrin signalling at a glance. J Cell Sci 2009; 122(Pt 2): 159-63.

[16] Legate KR, Wickstrom SA, Fassler R. Genetic and cell biological analysis of integrin outside-in signaling. Genes Dev 2009; 23(4): 397-418.

[17] Welsh CF, Assoian RK. A growing role for Rho family GTPases as intermediaries in growth factor- and adhesiondependent cell cycle progression. Biochim Biophys Acta 2000; 1471(1): M21-9.

[18] Hanks SK, Calalb MB, Harper MC, et al. Focal adhesion protein-tyrosine kinase phosphorylated in response to cell attachment to fibronectin. Proc Natl Acad Sci U S A 1992; 89(18): 8487-91.

[19] Huveneers S, Truong $H$, Danen HJ. Integrins: signaling, disease, and therapy. Int J Radiat Biol 2007; 83(11-12): 74351.

[20] Kim SH, Turnbull J, Guimond S. Extracellular matrix and cell signalling: the dynamic cooperation of integrin, proteoglycan and growth factor receptor. J Endocrinol 2011; 209(2): 13951.

[21] Kim SH. Antagonistic effect of EGF on FAK phosphorylation/dephosphorylation in a cell. Cell Biochem Funct 2008; 26(5): 539-47.

[22] Slack-Davis JK, Eblen ST, Zecevic M, et al. PAK1 phosphorylation of MEK1 regulates fibronectin-stimulated MAPK activation. J Cell Biol 2003; 162(2): 281-91.

[23] Edin ML, Juliano RL. Raf-1 serine 338 phosphorylation plays a key role in adhesion-dependent activation of extracellular signal-regulated kinase by epidermal growth factor. Mol Cell Biol 2005; 25(11): 4466-75.

[24] Sheppard D. Functions of pulmonary epithelial integrins: from development to disease. Physiol Rev 2003; 83(3): 673-86.

[25] Coraux C, Delplanque A, Hinnrasky J, et al. Distribution of integrins during human fetal lung development. J Histochem Cytochem 1998; 46(7): 803-10.

[26] Wagner TE, Frevert CW, Herzog EL, et al. Expression of the integrin subunit alpha8 in murine lung development. $\mathrm{J}$ Histochem Cytochem 2003; 51(10): 1307-15.

[27] Wu JE, Santoro SA. Differential expression of integrin alpha subunits supports distinct roles during lung branching morphogenesis. Dev Dyn 1996; 206(2): 169-81.

[28] Cambier S, Mu DZ, O'Connell D, et al. A role for the integrin alphavbeta8 in the negative regulation of epithelial cell growth. Cancer Res 2000; 60(24): 7084-93.

[29] Damjanovich L, Albelda SM, Mette SA, et al. Distribution of integrin cell adhesion receptors in normal and malignant lung tissue. Am J Respir Cell Mol Biol 1992; 6(2): 197-206.

[30] Mette SA, Pilewski J, Buck CA, et al. Distribution of integrin cell adhesion receptors on normal bronchial epithelial cells and lung cancer cells in vitro and in vivo. Am J Respir Cell Mol Biol 1993; 8(5): 562-72.

[31] Palmer EL, Ruegg C, Ferrando R, et al. Sequence and tissue distribution of the integrin alpha 9 subunit, a novel partner of beta 1 that is widely distributed in epithelia and muscle. $J$ Cell Biol 1993; 123(5): 1289-97.

[32] Pilewski JM, Latoche JD, Arcasoy SM, et al. Expression of integrin cell adhesion receptors during human airway epithelial repair in vivo. Am J Physiol 1997; 273(1 Pt 1): L256-63.

[33] Weinacker A, Ferrando R, Elliott $M$, et al. Distribution of integrins alpha $v$ beta 6 and alpha 9 beta 1 and their known ligands, fibronectin and tenascin, in human airways. Am J Respir Cell Mol Biol 1995; 12(5): 547-56.

[34] Korhonen M, Ylänne J, Laitinen L, et al. The alpha 1-alpha 6 subunits of integrins are characteristically expressed in distinct segments of developing and adult human nephron. $\mathrm{J}$ Cell Biol 1990; 111(3): 1245-54.

[35] Kadoya Y, Kadoya K, Durbeej M, et al. Antibodies against domain E3 of laminin-1 and integrin alpha 6 subunit perturb branching epithelial morphogenesis of submandibular gland, but by different modes. J Cell Biol 1995; 129(2): 521-34.

[36] Sorokin L, Sonnenberg A, Aumailley M, et al. Recognition of the laminin E8 cell-binding site by an integrin possessing the alpha 6 subunit is essential for epithelial polarization in developing kidney tubules. J Cell Biol 1990; 111(3): 1265-73.

[37] Carter WG, Wayner EA, Bouchard TS, et al. The role of integrins alpha 2 beta 1 and alpha 3 beta 1 in cell-cell and cell-substrate adhesion of human epidermal cells. J Cell Biol 1990; 110(4): 1387-404.

[38] Sriramarao P, Steffner P, Gehlsen KR. Biochemical evidence for a homophilic interaction of the alpha 3 beta 1 integrin. J Biol Chem 1993; 268(29): 22036-41.

[39] Symington BE, Takada Y, Carter WG. Interaction of integrins alpha 3 beta 1 and alpha 2 beta 1: potential role in keratinocyte intercellular adhesion. J Cell Biol 1993; 120(2): 523-35.

[40] Tenchini ML, Adams JC, Gilberty C, et al. Evidence against a major role for integrins in calcium-dependent intercellular adhesion of epidermal keratinocytes. Cell Adhes Commun 1993; 1(1): 55-66.

[41] Weitzman JB, Chen A, Hemler ME. Investigation of the role of beta 1 integrins in cell-cell adhesion. J Cell Sci 1995; 108 (Pt 11): 3635-44.

[42] Weitzman JB, Pasqualini R, Takada $Y$, et al. The function and distinctive regulation of the integrin VLA-3 in cell adhesion, spreading, and homotypic cell aggregation. J Biol Chem 1993; 268(12): 8651-7.

[43] Georges-Labouesse E, Messaddeq N, Yehia G, et al. Absence of integrin alpha 6 leads to epidermolysis bullosa and neonatal death in mice. Nat Genet 1996; 13(3): 370-3.

[44] van der Neut R, Krimpenfort P, Calafat J, et al. Epithelial detachment due to absence of hemidesmosomes in integrin beta 4 null mice. Nat Genet 1996; 13(3): 366-9.

[45] Eto $\mathrm{K}$, Huet $\mathrm{C}$, Tarui $\mathrm{T}$, et al. Functional classification of ADAMs based on a conserved motif for binding to integrin alpha 9beta 1: implications for sperm-egg binding and other cell interactions. J Biol Chem 2002; 277(20): 17804-10.

[46] Busk M, Pytela R, Sheppard D. Characterization of the integrin alpha $v$ beta 6 as a fibronectin-binding protein. $J$ Biol Chem 1992; 267(9): 5790-6.

[47] Roman J, Little CW, McDonald JA. Potential role of RGDbinding integrins in mammalian lung branching morphogenesis. Development 1991; 112(2): 551-8.

[48] Singh B, Fu C, Bhattacharya J. Vascular expression of the alpha(v)beta(3)-integrin in lung and other organs. Am J Physiol Lung Cell Mol Physiol 2000; 278(1): L217-26.

[49] Berlin M, Lundahl J, Skold CM, et al. The lymphocytic alveolitis in sarcoidosis is associated with increased amounts of soluble and cell-bound adhesion molecules in bronchoalveolar lavage fluid and serum. J Intern Med 1998; 244(4): 333-40.

[50] Shigehara K, Shijubo N, Hirasawa $\mathrm{M}$, et al. Immunolocalization of extracellular matrix proteins and integrins in sarcoid lymph nodes. Virchows Arch 1998; 433(1): 55-61.

[51] White ES, Thannickal VJ, Carskadon SL, et al. Integrin alpha4beta1 regulates migration across basement membranes by lung fibroblasts: a role for phosphatase and tensin homologue deleted on chromosome 10. Am J Respir Crit Care Med 2003; 168(4): 436-42.

[52] Zhu CQ, Popova SN, Brown ER, et al. Integrin alpha 11 regulates IGF2 expression in fibroblasts to enhance tumorigenicity of human non-small-cell lung cancer cells. Proc Natl Acad Sci U S A 2007; 104(28): 11754-9.

[53] Freyer A, Johnson S, Hall I. Effects of growth factors and extracellular matrix on survival of human airway smooth muscle cells. Am J Respir Cell Mol Biol 2001; 25(5): 569-76.

[54] Tran T, Ens-Blackie K, Rector ES, et al. Laminin-binding integrin alpha7 is required for contractile phenotype expression by human airway myocytes. Am J Respir Cell Mol Biol 2007; 37(6): 668-80.

[55] Lohmeyer J, Friedrich J, Grimminger F, et al. Expression of mucosa-related integrin alphaEbeta7 on alveolar $\mathrm{T}$ cells in 
interstitial lung diseases. Clin Exp Immunol 1999; 116(2): 340-6.

[56] Tatler $A L$, John $A E$, Jolly $L$, et al. Integrin avß5-mediated TGF- $\beta$ activation by airway smooth muscle cells in asthma. J Immunol 2011; 187(11): 6094-107.

[57] Senger DR, Claffey KP, Benes JE, et al. Angiogenesis promoted by vascular endothelial growth factor: regulation through alpha1beta1 and alpha2beta1 integrins. Proc Natl Acad Sci U S A 1997; 94(25): 13612-7.

[58] Macias-Perez I, Borza C, Chen X, et al. Loss of integrin alpha1beta1 ameliorates Kras-induced lung cancer. Cancer Res 2008; 68(15): 6127-35.

[59] Berlin M, Lundahl J, Sköld CM, et al. The lymphocytic alveolitis in sarcoidosis is associated with increased amounts of soluble and cell-bound adhesion molecules in bronchoalveolar lavage fluid and serum. J Intern Med 1998; 244(4): 333-40.

[60] Ohashi Y, Motojima S, Fukuda T, et al. Airway hyperresponsiveness, increased intracellular spaces of bronchial epithelium, and increased infiltration of eosinophils and lymphocytes in bronchial mucosa in asthma. Am Rev Respir Dis 1992; 145(6): 1469-76.

[61] Nagata M, Yamamoto $H$, Tabe $\mathrm{K}$, et al. Eosinophil transmigration across VCAM-1-expressing endothelial cells is upregulated by antigen-stimulated mononuclear cells. Int Arch Allergy Immunol 2001; 125 Suppl 1: 7-11.

[62] Hocking DC. Fibronectin matrix deposition and cell contractility: implications for airway remodeling in asthma. Chest 2002; 122 (6 Suppl): 275S-8S.

[63] Han JY, Kim HS, Lee SH, et al. Immunohistochemical expression of integrins and extracellular matrix proteins in non-small cell lung cancer: correlation with lymph node metastasis. Lung Cancer 2003; 41(1): 65-70.

[64] Huang XZ, Wu JF, Cass D, et al. Inactivation of the integrin beta 6 subunit gene reveals a role of epithelial integrins in regulating inflammation in the lung and skin. J Cell Biol 1996; 133(4): 921-8.

[65] Morris DG, Huang $X$, Kaminski $N$, et al. Loss of integrin alpha(v)beta6-mediated TGF-beta activation causes Mmp12dependent emphysema. Nature 2003; 422(6928): 169-73.

[66] Sheppard D. Roles of alphav integrins in vascular biology and pulmonary pathology. Curr Opin Cell Biol 2004; 16(5): 552-7.

[67] Wipff PJ, Rifkin DB, Meister JJ, et al. Myofibroblast contraction activates latent TGF-beta1 from the extracellular matrix. J Cell Biol 2007; 179(6): 1311-23.

[68] Horan GS, Wood S, Ona V, et al. Partial inhibition of integrin alpha(v)beta6 prevents pulmonary fibrosis without exacerbating inflammation. Am J Respir Crit Care Med 2008; 177(1): 56-65.

[69] John AE, Luckett JC, Tatler AL, et al. Preclinical SPECT/CT imaging of $\alpha v \beta 6$ integrins for molecular stratification of idiopathic pulmonary fibrosis. J Nucl Med 2013; 54(12): 2146-52.

[70] Jenkins RG, Su X, Su G, et al. Ligation of protease-activated receptor 1 enhances alpha(v)beta6 integrin-dependent TGFbeta activation and promotes acute lung injury. J Clin Invest 2006; 116(6): 1606-14.

[71] Xu MY, Porte J, Knox AJ, et al. Lysophosphatidic acid induces alphavbeta6 integrin-mediated TGF-beta activation via the LPA2 receptor and the small $G$ protein $G$ alpha(q). Am J Pathol 2009; 174(4): 1264-79.

[72] Jolly L, Stavrou A, Vanderstoken G, et al. Influenza promotes collagen deposition via av $\beta 6$ integrin-mediated transforming growth factor $\beta$ activation. J Biol Chem 2014; 289(51): 35246-63.

[73] Konishi K, Gibson KF, Lindell KO, et al. Gene expression profiles of acute exacerbations of idiopathic pulmonary fibrosis. Am J Respir Crit Care Med 2009; 180(2): 167-75.

[74] Benayoun L, Druilhe A, Dombret M, et al. Airway structural alterations selectively associated with severe asthma. Am J Respir Crit Care Med 2003; 167(10): 1360-8.

[75] Tran T, Teoh CM, Tam JK, et al. Laminin drives survival signals to promote a contractile smooth muscle phenotype and airway hyperreactivity. FASEB J 2013; 27(10): 39914003.

[76] Lambert RK, Wiggs BR, Kuwano K, et al. Functional significance of increased airway smooth muscle in asthma and COPD. J Appl Physiol 1993; 74(6): 2771-81.

[77] Christie PE, Jonas $\mathrm{M}$, Tsai $\mathrm{CH}$, et al. Increase in laminin expression in allergic airway remodelling and decrease by dexamethasone. Eur Respir J 2004; 24(1): 107-15.

[78] Rihs S, Walker C, Virchow JC, Jr, et al. Differential expression of alpha $E$ beta 7 integrins on bronchoalveolar lavage $\mathrm{T}$ lymphocyte subsets: regulation by alpha 4 beta 1integrin crosslinking and TGF-beta. Am J Respir Cell Mol Biol 1996; 15(5): 600-10.

[79] Leckie MJ, Jenkins GR, Khan J, et al. Sputum T lymphocytes in asthma, COPD and healthy subjects have the phenotype of activated intraepithelial T cells (CD69+ CD103+). Thorax 2003; 58(1): 23-9.

[80] Lawler J. The functions of thrombospondin-1 and-2. Curr Opin Cell Biol 2000; 12(5): 634-40.

[81] Lawler J, Sunday M, Thibert V, et al. Thrombospondin-1 is required for normal murine pulmonary homeostasis and its absence causes pneumonia. J Clin Invest 1998; 101(5): 98292.

[82] Yabkowitz R, Dixit VM, Guo N, et al. Activated T-cell adhesion to thrombospondin is mediated by the alpha 4 beta 1 (VLA-4) and alpha 5 beta 1 (VLA-5) integrins. J Immunol 1993; 151(1): 149-58.

[83] Mansfield PJ, Boxer LA, Suchard SJ. Thrombospondin stimulates motility of human neutrophils. J Cell Biol 1990; 111(6 Pt 2): 3077-86.

[84] Mansfield PJ, Suchard SJ. Thrombospondin promotes chemotaxis and haptotaxis of human peripheral blood monocytes. J Immunol 1994; 153(9): 4219-29.

[85] Huber AR, Ellis S, Johnson KJ, et al. Monocyte diapedesis through an in vitro vessel wall construct: inhibition with monoclonal antibodies to thrombospondin. J Leukoc Biol 1992; 52(5): 524-8.

[86] Guo N, Templeton NS, Al-Barazi H, et al. Thrombospondin-1 promotes alpha3beta1 integrin-mediated adhesion and neurite-like outgrowth and inhibits proliferation of small cell lung carcinoma cells. Cancer Res 2000; 60(2): 457-66.

[87] Ezzie ME, Piper MG, Montague C, et al. Thrombospondin-1deficient mice are not protected from bleomycin-induced pulmonary fibrosis Am J Respir Cell Mol Biol 2011; 44(4): 556-61.

[88] Sheppard D. Transforming growth factor beta: a central modulator of pulmonary and airway inflammation and fibrosis. Proc Am Thorac Soc 2006; 3(5): 413-7.

[89] Munger JS, Huang $X$, Kawakatsu $H$, et al. The integrin alpha $v$ beta 6 binds and activates latent TGF beta 1: a mechanism for regulating pulmonary inflammation and fibrosis. Cell 1999; 96(3): 319-28.

[90] Clark CJ, Sage EH. A prototypic matricellular protein in the tumor microenvironment--where there's SPARC, there's fire. J Cell Biochem 2008; 104(3): 721-32.

[91] Kuhn C, Mason RJ. Immunolocalization of SPARC, tenascin, and thrombospondin in pulmonary fibrosis. Am $\mathrm{J}$ Pathol 1995; 147(6): 1759-69.

[92] Sage H, Vernon RB, Funk SE, et al. SPARC, a secreted protein associated with cellular proliferation, inhibits cell spreading in vitro and exhibits $\mathrm{Ca}+2$-dependent binding to the extracellular matrix. J Cell Biol 1989; 109(1): 341-56.

[93] Francki A, Bradshaw AD, Bassuk JA, et al. SPARC regulates the expression of collagen type I and transforming growth factor-beta1 in mesangial cells. J Biol Chem 1999; 274(45): 32145-52.

[94] Gruber HE, Sage EH, Norton HJ, et al. Targeted deletion of the SPARC gene accelerates disc degeneration in the aging mouse. J Histochem Cytochem 2005; 53(9): 1131-8.

[95] Bradshaw AD, Puolakkainen P, Dasgupta J, et al. SPARCnull mice display abnormalities in the dermis characterized by decreased collagen fibril diameter and reduced tensile strength. J Invest Dermatol 2003; 120(6): 949-55.

[96] Barker TH, Baneyx G, Cardó-Vila M, et al. SPARC regulates extracellular matrix organization through its modulation of 
integrin-linked kinase activity. J Biol Chem 2005; 280(43): 36483-93.

[97] Chang W, Wei K, Jacobs SS, et al. SPARC suppresses apoptosis of idiopathic pulmonary fibrosis fibroblasts through constitutive activation of beta-catenin. J Biol Chem 2010; 285(11): 8196-206.

[98] Takayama G, Arima K, Kanaji T, et al. Periostin: a novel component of subepithelial fibrosis of bronchial asthma downstream of IL-4 and IL-13 signals. J Allergy Clin Immunol 2006; 118(1): 98-104.

[99] Blanchard C, Mingler MK, McBride $M$, et al. Periostin facilitates eosinophil tissue infiltration in allergic lung and esophageal responses. Mucosal Immunol 2008; 1(4): 28996.

[100] Gillan L, Matei D, Fishman DA, et al. Periostin secreted by epithelial ovarian carcinoma is a ligand for alpha(V)beta(3) and alpha(V)beta(5) integrins and promotes cell motility. Cancer Res 2002; 62(18): 5358-64.

[101] Sehra S, Yao W, Nguyen ET, et al. Periostin regulates goblet cell metaplasia in a model of allergic airway inflammation. J Immunol 2011; 186(8): 4959-66.

[102] Thai $P$, Loukoianov A, Wachi S, et al. Regulation of airway mucin gene expression. Annu Rev Physiol 2008; 70: 405-29.

[103] Ouyang G, Liu M, Ruan K, et al. Upregulated expression of periostin by hypoxia in non-small-cell lung cancer cells promotes cell survival via the Akt/PKB pathway. Cancer Lett 2009; 281(2): 213-9.

[104] Bao S, Ouyang G, Bai X, et al. Periostin potently promotes metastatic growth of colon cancer by augmenting cell survival via the Akt/PKB pathway. Cancer Cell 2004; 5(4): 329-39.

[105] Naik PK, Bozyk PD, Bentley JK, et al. Periostin promotes fibrosis and predicts progression in patients with idiopathic pulmonary fibrosis. Am J Physiol Lung Cell Mol Physiol 2012; 303(12): L1046-56.

[106] Okamoto M, Hoshino T, Kitasato $\mathrm{Y}$, et al. Periostin, a matrix protein, is a novel biomarker for idiopathic interstitial pneumonias. Eur Respir J 2011; 37(5): 1119-27.

[107] Uchida M, Shiraishi H, Ohta S, et al. Periostin, a matricellular protein, plays a role in the induction of chemokines in pulmonary fibrosis. Am J Respir Cell Mol Biol 2012; 46(5): 677-86.

[108] Pozzi A, Moberg PE, Miles LA, et al. Elevated matrix metalloprotease and angiostatin levels in integrin alpha 1 knockout mice cause reduced tumor vascularization. Proc Natl Acad Sci U S A 2000; 97(5): 2202-7.

[109] Kreidberg JA, Donovan MJ, Goldstein SL, et al. Alpha 3 beta 1 integrin has a crucial role in kidney and lung organogenesis. Development 1996; 122(11): 3537-47.

[110] DiPersio CM, Hodivala-Dilke KM, Jaenisch $\mathrm{R}$, et al. alpha3beta1 Integrin is required for normal development of the epidermal basement membrane. J Cell Biol 1997; 137(3): 729-42.

[111] Anton ES, Kreidberg JA, Rakic P. Distinct functions of alpha3 and alpha( $\mathrm{v})$ integrin receptors in neuronal migration and laminar organization of the cerebral cortex. Neuron 1999; 22(2): 277-89.

[112] Georges-Labouesse E, Mark M, Messaddeq N, et al. Essential role of alpha 6 integrins in cortical and retinal lamination. Curr Biol 1998; 8(17): 983-6.

[113] De Arcangelis A, Mark M, Kreidberg J, et al. Synergistic activities of alpha3 and alpha 6 integrins are required during apical ectodermal ridge formation and organogenesis in the mouse. Development 1999; 126(17): 3957-68.

[114] Huang XZ, Wu JF, Ferrando R, et al. Fatal bilateral chylothorax in mice lacking the integrin alpha9beta1. Mol Cell Biol 2000; 20(14): 5208-15.

[115] Su G, Hodnett M, Wu N, et al. Integrin alphavbeta5 regulates lung vascular permeability and pulmonary endothelial barrier function Am J Respir Cell Mol Biol 2007; 36(3): 377-86.

[116] Kikuchi M, Tachimoto H, Nutku E, et al. Phorbol esters alter alpha4 and alphad integrin usage during eosinophil adhesion to VCAM-1. Cell Commun Adhes 2003; 10(3): 119-28.
[117] Bayless KJ, Meininger GA, Scholtz JM, et al. Osteopontin is a ligand for the alpha4beta1 integrin. J Cell Sci 1998; 111 (Pt 9): $1165-74$

[118] Bocchino V, Bertorelli G, D'Ippolito R, et al. The increased number of very late activation antigen-4-positive cells correlates with eosinophils and severity of disease in the induced sputum of asthmatic patients. J Allergy Clin Immunol 2000; 105(1 Pt 1): 65-70.

[119] Cox D, Brennan M, Moran N. Integrins as therapeutic targets: lessons and opportunities. Nat Rev Drug Discov 2013; 9(10): 804-20.

[120] Norris V, Choong L, Tran D, et al. Effect of IVL745, a VLA-4 antagonist, on allergen-induced bronchoconstriction in patients with asthma. J Allergy Clin Immunol 2005; 116(4): 761-7.

[121] Davies DE, Wicks J, Powell RM, et al. Airway remodeling in asthma: new insights. J Allergy Clin Immunol 2003; 111(2): 215-25.

[122] McMillan SJ, Xanthou G, Lloyd CM. Manipulation of allergeninduced airway remodeling by treatment with anti-TGF-beta antibody: effect on the Smad signaling pathway. J Immunol 2005; 174(9): 5774-80.

[123] Churg A, Zhou S, Wang X, et al. The role of interleukin-1beta in murine cigarette smoke-induced emphysema and small airway remodeling. Am J Respir Cell Mol Biol 2009; 40(4): 482-90.

[124] Podowski M, Calvi C, Metzger S, et al. Angiotensin receptor blockade attenuates cigarette smoke-induced lung injury and rescues lung architecture in mice. J Clin Invest 2012; 122(1): 229-40.

[125] Kitamura H, Cambier S, Somanath S, et al. Mouse and human lung fibroblasts regulate dendritic cell trafficking, airway inflammation, and fibrosis through integrin $\alpha v \beta 8$ mediated activation of TGF- $\beta$. J Clin Invest 2011; 121(7): 2863-75.

[126] Wang Z, Chui WK, Ho PC. Integrin targeted drug and gene delivery. Expert Opin Drug Deliv 2010; 7(2): 159-71.

[127] Ellerby HM, Arap W, Ellerby LM, et al. Anti-cancer activity of targeted pro-apoptotic peptides. Nat Med 1999; 5(9): 1032-8.

[128] Reardon DA, Neyns B, Weller M, et al. Cilengitide: an RGD pentapeptide $\alpha v \beta 3$ and $\alpha v \beta 5$ integrin inhibitor in development for glioblastoma and other malignancies. Future Oncol 2011; 7(3): 339-54.

[129] Kuwada SK. Drug evaluation: Volociximab, an angiogenesisinhibiting chimeric monoclonal antibody. Curr Opin Mol Ther 2007; 9(1): 92-8.

[130] Francis SE, Goh KL, Hodivala-Dilke K, et al. Central roles of alpha5beta1 integrin and fibronectin in vascular development in mouse embryos and embryoid bodies. Arterioscler Thromb Vasc Biol 2002; 22(6): 927-33.

[131] Sudhakar A, Sugimoto H, Yang C, et al. Human tumstatin and human endostatin exhibit distinct antiangiogenic activities mediated by alpha $\vee$ beta 3 and alpha 5 beta 1 integrins. Proc Natl Acad Sci U S A 2003; 100(8): 4766-71.

[132] Pedchenko V, Zent R, Hudson BG. Alpha(v)beta3 and alpha(v)beta5 integrins bind both the proximal RGD site and non-RGD motifs within noncollagenous (NC1) domain of the alpha3 chain of type IV collagen: implication for the mechanism of endothelia cell adhesion. J Biol Chem 2004; 279(4): 2772-80.

[133] Marneros AG, Olsen BR. The role of collagen-derived proteolytic fragments in angiogenesis. Matrix Biol 2001; 20(56): 337-45.

[134] Marcinkiewicz C, Weinreb PH, Calvete JJ, et al. Obtustatin: a potent selective inhibitor of alpha1beta1 integrin in vitro and angiogenesis in vivo. Cancer Res 2003; 63(9): 2020-3.

[135] Nakamura T, Lozano PR, Ikeda Y, et al. Fibulin-5/DANCE is essential for elastogenesis in vivo. Nature 2002; 415(6868): 171-5.

[136] White SR, Dorscheid DR, Rabe KF, et al. Role of very late adhesion integrins in mediating repair of human airway epithelial cell monolayers after mechanical injury. Am J Respir Cell Mol Biol 1999; 20(4): 787-96.

[137] Adachi M, Taki T, Higashiyama $M$, et al. Significance of integrin alpha5 gene expression as a prognostic factor in 
node-negative non-small cell lung cancer. Clin Cancer Res 2000; 6(1): 96-101.

[138] Caccavari F, Valdembri D, Sandri C, et al. Integrin signaling and lung cancer. Cell Adh Migr 2010; 4(1): 124-9.

[139] Wu H, Zhang $Y, X u ~ Z$, et al. The expression of integrin alpha5beta1 and transforming growth factor-beta in pulmonary fibrosis of rat. Zhonghua Bing Li Xue Za Zhi 1999; 28(6): 427-31.

[140] Saltini C, Hemler ME, Crystal RG. T lymphocytes compartmentalized on the epithelial surface of the lower respiratory tract express the very late activation antigen complex VLA-1. Clin Immunol Immunopathol 1988; 46(2): 221-33.

[141] Gardner H, Kreidberg J, Koteliansky V, et al. Deletion of integrin alpha 1 by homologous recombination permits normal murine development but gives rise to a specific deficit in cell adhesion. Dev Biol 1996; 175(2): 301-13.

[142] Pozzi A, Wary KK, Giancotti FG, et al. Integrin alpha1beta1 mediates a unique collagen-dependent proliferation pathway in vivo. J Cell Biol 1998; 142(2): 587-94.

[143] Gardner HA. Integrin signaling in fibrosis and scleroderma. Curr Rheumatol Rep 1999; 1(1): 28-33.

[144] Holtkotter O, Nieswandt B, Smyth N, et al. Integrin alpha 2deficient mice develop normally, are fertile, but display partially defective platelet interaction with collagen. $\mathrm{J}$ Biol Chem 2002; 277(13): 10789-94.

[145] Chen J, Diacovo TG, Grenache DG, et al. The alpha(2) integrin subunit-deficient mouse: a multifaceted phenotype including defects of branching morphogenesis and hemostasis. Am J Pathol 2002; 161(1): 337-44.

[146] Edelson BT, Li Z, Pappan LK, et al. Mast cell-mediated inflammatory responses require the alpha 2 beta 1 integrin. Blood 2004; 103(6): 2214-20.

[147] McCall-Culbreath KD, Li Z, Zutter MM. Crosstalk between the alpha2beta1 integrin and c-met/HGF-R regulates innate immunity. Blood 2008; 111(7): 3562-70.

[148] Menko AS, Kreidberg JA, Ryan TT, et al. Loss of alpha3beta1 integrin function results in an altered differentiation program in the mouse submandibular gland. Dev Dyn 2001; 220(4): 337-49.

[149] Yang JT, Rayburn H, Hynes RO. Cell adhesion events mediated by alpha 4 integrins are essential in placental and cardiac development. Development 1995; 121(2): 549-60.

[150] Arroyo AG, Yang JT, Rayburn $H$, et al. Differential requirements for alpha4 integrins during fetal and adult hematopoiesis. Cell 1996; 85(7): 997-1008.

[151] Arroyo AG, Taverna D, Whittaker CA, et al. In vivo roles of integrins during leukocyte development and traffic: insights from the analysis of mice chimeric for alpha 5 , alpha $v$, and alpha 4 integrins. J Immunol 2000; 165(8): 4667-75.

[152] Yang JT, Rayburn H, Hynes RO. Embryonic mesodermal defects in alpha 5 integrin-deficient mice. Development 1993; 119(4): 1093-105.

[153] Yang JT, Bader BL, Kreidberg JA, et al. Overlapping and independent functions of fibronectin receptor integrins in early mesodermal development. Dev Biol 1999; 215(2): 26477.

[154] Goh KL, Yang JT, Hynes RO. Mesodermal defects and cranial neural crest apoptosis in alpha5 integrin-null embryos. Development 1997; 124(21): 4309-19.

[155] Miner JH, Li C. Defective glomerulogenesis in the absence of laminin alpha5 demonstrates a developmental role for the kidney glomerular basement membrane. Dev Biol 2000; 217(2): 278-89.

[156] Mayer U, Saher G, Fassler R, et al. Absence of integrin alpha 7 causes a novel form of muscular dystrophy. Nat Genet 1997; 17(3): 318-23.

[157] Hayashi YK, Chou FL, Engvall E, et al. Mutations in the integrin alpha7 gene cause congenital myopathy. Nat Genet 1998; 19(1): 94-7.

[158] Muller U, Wang D, Denda S, et al. Integrin alpha8beta1 is critically important for epithelial-mesenchymal interactions during kidney morphogenesis. Cell 1997; 88(5): 603-13.
[159] Littlewood Evans A, Muller U. Stereocilia defects in the sensory hair cells of the inner ear in mice deficient in integrin alpha8beta1. Nat Genet 2000; 24(4): 424-8.

[160] Bader BL, Rayburn H, Crowley D, et al. Extensive vasculogenesis, angiogenesis, and organogenesis precede lethality in mice lacking all alpha v integrins. Cell 1998; 95(4): 507-19.

[161] Henderson NC, Arnold TD, Katamura Y, et al. Targeting of $\alpha v$ integrin identifies a core molecular pathway that regulates fibrosis in several organs. Nat Med 2013; 19(12): 1617-24.

[162] Schmits R, Kundig TM, Baker DM, et al. LFA-1-deficient mice show normal CTL responses to virus but fail to reject immunogenic tumor. J Exp Med 1996; 183(4): 1415-26.

[163] Shier P, Ngo K, Fung-Leung WP. Defective CD8+ T cell activation and cytolytic function in the absence of LFA-1 cannot be restored by increased TCR signaling. J Immunol 1999; 163(9): 4826-32.

[164] Berlin-Rufenach C, Otto F, Mathies M, et al. Lymphocyte migration in lymphocyte function-associated antigen (LFA)-1deficient mice. J Exp Med 1999; 189(9): 1467-78.

[165] Coxon A, Rieu P, Barkalow FJ, et al. A novel role for the beta 2 integrin CD11b/CD18 in neutrophil apoptosis: a homeostatic mechanism in inflammation. Immunity 1996; 5(6): 653-66.

[166] Rosenkranz AR, Coxon A, Maurer M, et al. Impaired mast cell development and innate immunity in Mac-1 (CD11b/CD18, CR3)-deficient mice. J Immunol 1998; 161(12): 6463-7.

[167] Dong ZM, Gutierrez-Ramos JC, Coxon A, et al. A new class of obesity genes encodes leukocyte adhesion receptors. Proc Natl Acad Sci U S A 1997; 94(14): 7526-30.

[168] Schon MP, Arya A, Murphy EA, et al. Mucosal T lymphocyte numbers are selectively reduced in integrin alpha $E$ (CD103)deficient mice. J Immunol 1999; 162(11): 6641-9.

[169] Tronik-Le Roux D, Roullot V, Poujol C, et al. Thrombasthenic mice generated by replacement of the integrin alpha(IIb) gene: demonstration that transcriptional activation of this megakaryocytic locus precedes lineage commitment. Blood 2000; 96(4): 1399-408.

[170] Fassler R, Meyer M. Consequences of lack of beta 1 integrin gene expression in mice. Genes Dev 1995; 9(15): 1896-908.

[171] Stephens LE, Sutherland AE, Klimanskaya IV, et al. Deletion of beta 1 integrins in mice results in inner cell mass failure and peri-implantation lethality. Genes Dev 1995; 9(15): 188395.

[172] Hirsch E, Iglesias A, Potocnik AJ, et al. Impaired migration but not differentiation of haematopoietic stem cells in the absence of beta1 integrins. Nature 1996; 380(6570): 171-5

[173] Potocnik AJ, Brakebusch C, Fassler R. Fetal and adult hematopoietic stem cells require beta1 integrin function for colonizing fetal liver, spleen, and bone marrow. Immunity 2000; 12(6): 653-63.

[174] Keller RS, Shai SY, Babbitt CJ, et al. Disruption of integrin function in the murine myocardium leads to perinatal lethality, fibrosis, and abnormal cardiac performance. Am J Pathol 2001; 158(3): 1079-90.

[175] Scharffetter-Kochanek K, Lu H, Norman K, et al. Spontaneous skin ulceration and defective $T$ cell function in CD18 null mice. J Exp Med 1998; 188(1): 119-31.

[176] Mizgerd JP, Kubo H, Kutkoski GJ, et al. Neutrophil emigration in the skin, lungs, and peritoneum: different requirements for CD11/CD18 revealed by CD18-deficient mice. J Exp Med 1997; 186(8): 1357-64

[177] Schneeberger EE, Vu Q, LeBlanc BW, et al. The accumulation of dendritic cells in the lung is impaired in CD18-/- but not in ICAM-1-/- mutant mice. J Immunol 2000; 164(5): 2472-8.

[178] Hodivala-Dilke KM, McHugh KP, Tsakiris DA, et al. Beta3integrin-deficient mice are a model for Glanzmann thrombasthenia showing placental defects and reduced survival. J Clin Invest 1999; 103(2): 229-38.

[179] McHugh KP, Hodivala-Dilke K, Zheng MH, et al. Mice lacking beta3 integrins are osteosclerotic because of dysfunctional osteoclasts. J Clin Invest 2000; 105(4): 433-40. 
[180] Zimmerman D, Jin F, Leboy P, et al. Impaired bone formation in transgenic mice resulting from altered integrin function in osteoblasts. Dev Biol 2000; 220(1): 2-15.

[181] Dowling J, Yu QC, Fuchs E. Beta4 integrin is required for hemidesmosome formation, cell adhesion and cell survival. J Cell Biol 1996; 134(2): 559-72.

[182] Huang $X$, Griffiths $M, W u$ J, et al. Normal development, wound healing, and adenovirus susceptibility in beta5deficient mice. Mol Cell Biol 2000; 20(3): 755-9.

[183] Wagner N, Lohler J, Kunkel EJ, et al. Critical role for beta7 integrins in formation of the gut-associated lymphoid tissue. Nature 1996; 382(6589): 366-70.

[184] Zhu J, Motejlek K, Wang D, et al. beta8 integrins are required for vascular morphogenesis in mouse embryos. Development 2002; 129(12): 2891-903.

[185] Ding ZM, Babensee JE, Simon SI, et al. Relative contribution of LFA-1 and Mac-1 to neutrophil adhesion and migration. J Immunol 1999; 163(9): 5029-38.

[186] Pulkkinen L, Uitto J. Mutation analysis and molecular genetics of epidermolysis bullosa. Matrix Biol 1999; 18(1): 29-42.

[187] Miner JH, Cunningham J, Sanes JR. Roles for laminin in embryogenesis: exencephaly, syndactyly, and placentopathy in mice lacking the laminin alpha5 chain. J Cell Biol 1998; 143(6): 1713-23.

[188] Wagner N, Lohler J, Tedder TF, et al. L-selectin and beta7 integrin synergistically mediate lymphocyte migration to mesenteric lymph nodes. Eur J Immunol 1998; 28(11): 38329.

Received: January 31, 2015
Accepted: May 13, 2015
[189] Lin K, Ateeq HS, Hsiung SH, et al. Selective, tight-binding inhibitors of integrin alpha4beta1 that inhibit allergic airway responses. J Med Chem 1999; 42(5): 920-34.

[190] Abraham WM, Gill A, Ahmed A, et al. A small-molecule, tightbinding inhibitor of the integrin alpha(4)beta(1) blocks antigen-induced airway responses and inflammation in experimental asthma in sheep. Am J Respir Crit Care Med 2000; 162(2 Pt 1): 603-11.

[191] Ravensberg AJ, Luijk B, Westers $P$, et al. The effect of a single inhaled dose of a VLA-4 antagonist on allergeninduced airway responses and airway inflammation in patients with asthma. Allergy 2006; 61(9): 1097-103.

[192] Diamant Z, Kuperus J, Baan R, et al. Effect of a very late antigen-4 receptor antagonist on allergen-induced airway responses and inflammation in asthma. Clin Exp Allergy 2005; 35(8): 1080-7.

[193] Sircar I, Gudmundsson KS, Martin R, et al. Synthesis and SAR of N-benzoyl-L-biphenylalanine derivatives: discovery of TR-14035, a dual alpha(4)beta(7)/alpha(4)beta(1) integrin antagonist. Bioorg Med Chem 2002; 10(6): 2051-66.

[194] Cortijo J, Sanz MJ, Iranzo A, et al. A small molecule, orally active, alpha4beta1/alpha4beta7 dual antagonist reduces leukocyte infiltration and airway hyper-responsiveness in an experimental model of allergic asthma in Brown Norway rats. Br J Pharmacol 2006; 147(6): 661-70.

[195] Beekman KW, Colevas AD, Cooney K, et al. Phase II evaluations of cilengitide in asymptomatic patients with androgen-independent prostate cancer: scientific rationale and study design. Clin Genitourin Cancer 2006; 4(4): 299302. 